\title{
TÜBİTAK Türkiye Adresli Uluslararası Bilimsel Yayınları Teşvik Programınca Desteklenen Dergiler Üzerine Bir Değerlendirme: Yayıncı Ülkeler ve Disiplin Farklılıklarına Yakından Bakış
}

\section{An Evaluation on Journals Supported by TÜBİTAK Incentive Program for International Scientific Publications: Closer Look at the Origins and Disciplines of the Journals}

\author{
Zehra Taşkın* ***
}

$\ddot{\boldsymbol{O}} z$

Bilimsel iletişim sürecinin en önemli aktörlerinden biri bilimsel dergilerdir. Bilimsel dergiler araştırma bulgularının sunulduğu en önemli kayıt ortamlarıdır ve bu ortamlar sayesinde bilimsel bilginin tüm dünyayla paylaşılması mümkün hale gelmektedir. Ancak günümüzde çeşitli yayınevlerine ait binlerce dergi yayımlanmakta ve bu dergilerin kalitesi ile ilgili pek çok soru işareti bulunmaktadır. Pek çok ülke bu sorunun üstesinden gelebilmek üzere dergiler için çeşitli düzeyleri içeren sinıflamalar geliştirmektedirler. Bu listeler akademik teşvik ve yükselmelerde kullanılabildiği gibi araştırmacılara yayın yapabilecekleri dergiler konusunda rehberlik etmesi için de kullanılabilmektedirler. Türkiye'de yayımlanan en önemli dergi listesi TÜBİTAK Türkiye Adresli Uluslararası Bilimsel Yayınları Teşvik Programına (UBYT) ait olan listedir. Temel amacı Türkiye adresli kaliteli yayın sayısını ve bu yayınların görünürlüğ̈̈nü artırmak olarak açıklanan UBYT'de dergiler 2019 yll itibariyle dört temel seviyede gruplandırlmakta bu dergilerde yayın yapan yazarlar program sayesinde ödüllendirilmektedir. Bu çalışmanın temel amacı UBYT dergi listesinde yer alan dergilerin yayımlandıkları ülkeler ve yayımlandıkları disiplinler dikkate alınarak değerlendirilmesi ve sonuçların sunulmasıdır. Bu amaç doğrultusunda UBYT 2019 listesinde yer alan 10.465 ve 2018 listesinde yer alan 12.888 dergi ile bu dergilerde yapılan Türkiye adresli yayınlara ilişkin istatistikler derinlemesine incelenmiştir. Araştırma sonuçlarına göre Türkiye adresli yayınların büyük çoğunluğu UBYT tarafindan en düşük seviyede sinıflandırılan dergilerde yayımlanmaktadır. Hesaplama yönteminin değiştirilmesi ile birlikte 2018 yılı dergi listesi ile 2019 yılı dergi listesinde dergilerin konumlarında önemli değişiklikler olduğu saptanmıştır. Bunun yanında UBYT dergi listesinin teşvik sınıflarında farklı disiplinlerin eşit şekilde temsil edilmediği sonucuna da ulaşılmıştır. Yüksek teşvik miktarları ile desteklenen dergilerin neredeyse tamamının Kuzey Amerika ve Avrupa ülkelerine ait dergiler olduğu ortaya çıkarılmış, Türkiye adresli tüm dergilerinin en düşük seviyede sınıflandı̆̆ı saptanmıştır. Araştırma

\footnotetext{
*Ziyaretçi Öğretim Üyesi, Adam Mickiewicz Üniversitesi Bilimsel İletişim Araştırma Grubu, Polonya.

E-posta: zehrayanar@gmail.com

Visiting Professor. Adam Mickiewicz University Scholarly Communication Research Group, Poland.

** Dr. Öğr. Üyesi. Hacettepe Üniversitesi, Bilgi ve Belge Yönetimi Bölümü.

Assistant Prof., Hacettepe University Department of Information Management, Turkey.
}

Geliş Tarihi - Received: 07.02.2020

Kabul Tarihi - Accepted: 17.06 .2020 
sonuçları mevcut UBYT sisteminin iyileştirilmesi süreçlerinde uygulamayı yürüten TÜBİTAK ULAKBIM'e yardımcr olabilecek bulgular sunmaktadır.

Anahtar Sözcükler: Bilimsel yayın teşviki; UBYT; bilimsel dergi listeleri; dergi sınıflandırması; performans değerlendirme.

\section{Abstract}

One of the most important actors in the scholarly communication process is scientific journals. Scientific journals are the most important environment, where research findings are presented, and thanks to these environments, it is possible to share scientific information all over the world. However, thousands of scientific journals are published and there are many question marks about the quality of these journals for the last couple of decades. Many countries develop journal classifications with various levels to overcome the quality problem. These lists are used for academic incentives and promotions, as well as to guide the researchers on journals where they can publish. In Turkey, one of the most important journal lists is provided by TÜBITTAK Incentive Program for International Scientific Publications (UBYT). The main objective of the program is to increase the number of high-quality publications authored by Turkey addressed scholars and to increase the visibility of the publications. The journals are grouped into four basic levels in the UBYT program, and the authors are awarded by the program in terms of the levels of the journals. The main aim of this study is to reveal whether the UBYT journal list considers regional and disciplinary differences. To achieve this aim, statistics and bibliometric data on the journals included in the 2018 and 2019 UBYT journal lists are obtained. The countries of origins of the journals and the subject areas are taken into consideration for the analyses. According to the results, most of the Turkey-addressed publications are published in low-level journals. With the change of the calculation method, significant changes are determined in the positions of the journals in 2018 and 2019 journal lists. In addition, it is concluded that not all disciplines are represented equally in the Program's levels. It is discovered that almost all the top-tier journals are the journals of North America and Europe. All Turkey-addressed journals are classified into the low-level journals. The results of the research provide findings that may help TÜBİTAK ULAKBIM to improve the processes in the existing UBYT system.

Keywords: Incentives for scientific papers; UBYT; scientific journal lists; journal classification; performance evaluation.

\section{Giriş}

Şimşekler ve yıldırımların elektrikle bir bağlantısı olabileceğini düşünen Benjamin Franklin, 1752 yılında meşhur uçurtma deneyini gerçekleştirir ve heyecan duyduğu buluşunu kaleme aldığı bir mektupla Royal Society of London'daki arkadaşı Peter Collinson'a anlatır (Franklin, 1752, p. 565). Ardından Volta 1800'de pili icat eder ve icat ettiği pile ilişkin ilk raporunu 20 Mart 1800'de Royal Society of London'ın başkanı Joseph Banks'e bir mektup aracılığ 30 y1l sonra Michael Faraday, Volta'nın pilini geliştirerek elektrik dinamosunu üretir ve tüm üretim sürecini Philosophical Transactions of Royal Society of London'da raporlar (Faraday, 
1832). En az 80 yıllık bu süreç dünyayı elektriğe kavuşturan küçük adımlardır ve tüm bu adımların bir araya gelmesini olanaklı kılan en önemli etmen yazılı bilimsel iletişim araçlarıdır. 1600'lü yılların ortalarında Fransa'da kurulan Le Journal des Sçavans ve İngiltere'de Royal Society of London tarafından yayımlanan Philosophical Transactions araştırmacıların kendi aralarında sürdürdükleri resmi olmayan bilimsel iletişim süreçlerini resmiyete dökmelerine ve gelecek nesiller için raporlamalarına öncü olan ilk bilimsel dergilerdir (Tenopir ve King, 2000). Bilimsel dergiler sayesinde tarih boyunca bilginin bilimsel çevrelerce tartışllabilmesi, geliştirilebilmesi, doğrulanabilmesi ve yenilenebilmesi mümkün olabilmiştir. Böylece bilim birikimli olarak ilerleyebilmiş ve yapılan her bir keşif bir öncekinin üzerine yeni bilgiler ekleyerek içinde bulunduğumuz dünyayı daha iyi anlamamızı sağlamıştır (Zeigler, 2012, s. 585).

Yıllar içinde sayıları artan akademik kuruluşlar, bu kuruluşlar arasındaki bilimsel rekabetin devasa boyutlara gelmesi, bilimsel gelişmelerin aynı zamanda ekonomik gelişimi de beraberinde getiriyor oluşu ile ülkeler arasında başlayan bilim savaşları, teknolojik gelişmeler, elektronik yayıncılık, araştırmacı sayısının artışı gibi çok çeşitli sebepler bilimsel dergilere ve yayınlara yüklenen anlamların yıllar içinde boyut değiştirmesine sebep olmuştur. Özellikle 1960 yılında Eugene Garfield'in Institute for Scientific Information'1 (ISI) kurmas1 (Clarivate, 2018) ve seçilmiş bilimsel dergileri kapsayan Web of Science'ı piyasaya sürmesi ile birlikte akademi için yeni bir dönem başlamıştır. Bu süreçte akademinin yönetici ve karar vericileri bilimin sayılarla ölçülebileceğini fark etmişler ve araştırma(c1)ların etkinliğini ürettikleri yayınlar ve bu yayınların yer aldığı dergilere ilişkin çeşitli istatistiklere dayanarak değerlendirmeye başlamışlardır. Ancak yayın sayısının inanılmaz boyutlara geldiği günümüzde yayınların eşit bir şekilde değerlendirilmesi ve analiz edilmesi giderek daha da zorlaşmaktadır. Yayımlanan çok sayıda dergi ve bu dergilerde yayımlanan milyonlarca makale yönetici ve karar vericilerin değerlendirme süreçlerini güçleştirmektedir. Süreli yayın rehberi ULRICH'e göre 2020 yılı itibariye tüm dünyada yayımlanan aktif dergi sayısı 218.496 ' dır. ${ }^{1}$ Bu dergilerin 85.566 'sı hakemli olarak işaretlenmiştir. $\mathrm{Bu}$ denli fazla sayıda derginin yayımlandığı ortamda yayın için doğru dergilerin seçimi ve bu dergilerde yayın yapılması da giderek zorlaşmaktadır. Buna çözüm olarak ise karar vericiler otorite dergi listeleri belirleyerek araştırmacıları "kaliteli" kabul ettikleri dergilere yönlendirme yolunu seçmeye başlamışlardır. Kaliteli dergilerin teşvik edilmesi ile ülkelerin veya kurumların üst düzey dergilerde yayımlanan akademik çıktılarının sayısının artırılması ve uluslararası arenada görünürlük kazanılması hedeflenmektedir.

Kaliteli kabul edilen dergilerin belirlenmesi sürecinde ise sıklıkla dergilere ilişkin bibliyometrik göstergeler kullanılmaktadır. Pek çok ülkede araştırma/cı performans değerlendirmeleri araştırmacıların yayınlarının ve bu yayınlara aldıkları atıfların yer aldığı dergilerin sayısal göstergelerine dayanmaktadır. Araştırma değerlendirmelerinde dergi etki faktörü dikkate alınarak başlatılan dergi temelli bu süreçte günümüzde dergilere ilişkin atıf yarı yaşam değerinden makale etki faktörüne, 5 yıllık etki faktöründen dergi kendine atıf oranına kadar pek çok gösterge performans değerlendirmelerinin kilit noktalarını oluşturmaktadır. Ancak

\footnotetext{
${ }^{1}$ Tarama 25 Ocak 2020 tarihinde gerçekleştirilmiştir.
} 
dergilerdeki atıf dağılımının çarpık olması, etki faktörünün ve doküman tiplerinin alana özgülüğü, hesaplama göstergelerine kolaylıkla erişilemiyor oluşu ve bu göstergelerin kolaylıkla manipüle edilebilmesi gibi sebeplerle bu gibi göstergelerin dikkatli kullanılması gerektiği son y1llarda literatürde üzerinde önemle durulan en hassas konulardan biridir (Adler, Ewing ve Taylor, 2009; "DORA", 2019; Vanclay, 2012). Tüm bu gelişme ve çabalara rağmen pek çok ülkede dergi listelerinin belirlenmesi ve araştırmacılara dergi tavsiye listesi sunulması oldukça yaygındır. $\mathrm{Bu}$ bağlamda bazı ülkeler dergi listelerinin oluşturulması aşamasında bibliyometrik göstergeleri yalnızca yol gösterici olarak kullanırken bazı ülkeler ise bir dizinde yer almayı ya da sayısal bir faktörün belirli bir değerin üzerinde olmasını ilgili listelerde yer bulabilmek için yeter sebep olarak görmektedir. Örneğin, Polonya'da dergi listelerinin oluşturulması aşamasında bibliyometrik göstergelerden yararlanıldığ ancak nihai listenin farklı disiplinlerden gelen uzmanlarca oluşturulduğu belirtilmektedir (Kulczycki, 2017). Çekya'da ise bibliyometrik göstergelere dayalı bir dergi değerlendirme sistemi bulunduğu aktarılmaktadır (Good, Vermeulen, Tiefenthaler ve Arnold, 2015).

Türkiye'de ise hem yayın teşviklerinde hem de akademik atama ve yükselmelerde dergiler çoğunlukla bibliyometrik göstergeler dikkate alınarak değerlendirilmektedir. Örneğin, Üniversitelerarası Kurul tarafından sosyal, beşeri ve idari bilimler için belirlenen doçentlik kriterlerinde (ÜAK, 2019) dergiler dizinlendikleri platforma ve ulusal/uluslararası olma durumlarına göre puanlanmaktadırlar. En yüksek puan SCI, SSCI ve A\&HCI'da dizinlenen makalelere verilmektedir. Doçentlik kriterleri herhangi bir dergi listesi sunmamasına rağmen özünde Web of Science dergi listesini kullanmaktadır. Ulusal dergiler için ise temel kaynak ULAKBİM tarafından dizinlenen dergiler olarak belirlenmiştir. Öte yandan, üniversitelerin sahip oldukları yükselme ve teşvik kriterlerinde de benzer bir yaklaşım sergilenmektedir. Örneğin, Hacettepe Üniversitesi Öğretim Üyeliğine Yükseltme ve Atanma Kriterlerine (2019) göre dergiler arasındaki düzey farklılıklarını belirleyebilmek için Web of Science'da dizinlenen dergiler kullanılmakta ancak buna ek olarak dergi çeyrek dilimleri ile ilgili bir ayrım bulunmaktadır. Buna göre atama ve yükselmelerde en çok değer atfedilen dergiler Journal Citation Reports veri tabanında yer alan her bir konu kategorisinin ilk \%25'lik diliminde yer alan dergilerdir. Her bir çeyrek dilim bir öncekinden daha düşük nitelikte görülmekte ve buna göre puanlanmaktadır. $\mathrm{Bu}$ kriterlere göre birinci çeyrekte özgün araştırma makalesi yazan bir akademisyen 40 puan alırken, ikinci çeyrekte 30 , üçüncü çeyrekte 20 ve son çeyrekte 10 puan almaktadır. ULAKBİM TRDizin'de yer alan Türkçe makalelere verilen puan ise 7'dir. Aynı üniversitenin kriterlerine göre sanat ve insan bilimleri dergileri Journal Citation Reports'ta dizinlenmediklerinden bu disiplinde yayımlanan makaleler uluslararası ise 20 , ulusal ise 10 puan almaktadırlar ("Hacettepe Üniversitesi Güzel Sanatlar Fakültesi Öğretim Üyeliğine Yükseltme ve Atama Kriterleri 2019", 2019). Yani sanat ve insan bilimleri alanındaki tüm dergilerin üçüncü çeyrekte yer aldığı kabul edilmektedir.

Türkiye adresli yayınların artışıı sağlamak üzere çalışan iki teşvik mekanizması olan Akademik Teşvik Ödeneği Yönetmeliği ile TÜBİTAK Türkiye Adresli Uluslararası Bilimsel Yayınları Teşvik (UBYT) Programının dergilere yaklaşımı farklılık gösterse de her ikisi de özünde 
bibliyometrik göstergelere dayanmaktadır. 2020 yılında güncellenen Akademik Teşvik Ödeneği Yönetmeliği de Hacettepe Üniversitesi atama kriterlerinde olduğu gibi dergilerin seviyelerini belirlemek üzere çeyrek dilimlerden yararlanmaktadır (Akademik Teşvik Ödeneği Yönetmeliğinde Değisşiklik Yapılmasına Dair Yönetmelik, 2020). Buna göre SCI ve SSCI'da ilk çeyrekte yer alan dergiler için katsayı 1 olarak hesaplanırken, ikinci çeyrek için bu katsayı 0,8, üçüncü çeyrek için 0,5 ve son çeyrek için ise $0,25^{\prime}$ tir. Sanat ve insan bilimleri alanı aynı Hacettepe Üniversitesi kriterlerinde olduğu gibi üçüncü çeyrekte değerlendirilmektedir.

1993 yılından beri TÜBITTAK tarafindan yürütülenve Türkiye adresli yayınların etki ve görünürlüğünü artırmayı hedefleyen UBYT programı (UBYT Hakkında, 2020) bir dergi listesine sahip olan tek programdır. Dergi listesi her yıl güncellenmekte ve o yılın listesinin hesaplama yöntemi UBYT Programı Uygulama Usul ve Esasları dokümanında detaylı olarak açıklanmaktadır (TÜBİTAK Türkiye Adresli Uluslararası Bilimsel Yayınları Teşvik (UBYT) Programı Uygulama Usul ve Esasları, 2018). Uzun yıllar farklı hesaplama yöntemleri uygulayan program bir süredir dergi listelerinin belirlenmesinde Journal Citation Reports veri tabanında sunulan makale etki puanı değerini kullanmaktadır. Makale etki puanı bir derginin makalelerinin yayımlandıktan sonraki ilk beş yıl içerisindeki ortalama etkilerini belirler (Article Influence Score, t.y.). Buna göre program kapsamında makale etki puanı 3 ve üzeri olan dergilerde makalesi yer alan yazarların yayın yaptıkları dergiler "Teşvik D" olarak sınıflanmakta ve yazarlara makale başına 15.000 ₹ ödeme yapılmaktadır. Makale etki puanı 2 ila 2,9 arasında olan dergiler için bu rakam 10.000 € (Teşvik C), 1,5 ila 1,9 arasında olanlar ise 7500 £'dir (Teşvik B). Kalan diğer dergiler ise makale etki puanları dikkate alınarak $500 €$ 'den 7499 €'ye varan yelpazede desteklenmektedirler (Teşvik A)(UBYT S.S.S., 2019). Makale etki puanına sahip olmayan dergiler ${ }^{2}$ için ise dergi çeyrek dilimine dayalı bir değerlendirme yapılmaktadır. Buna göre birinci çeyrekteki dergiler 7500 €, ikinci çeyrekteki dergiler ise 3750 £ ödeme almaktadır. Makale etki puanı olmayan A\&HCI dergilerinin tamamı 2000 € desteklenerek son teşvik grubunda değerlendirilmektedir. UBYT’de yayın tipine göre de bir sınıflama bulunmaktadır. Buna göre makaleler için teşvik katsayısı 1 iken, derlemeler için bu sayı 0,5'tir. Ödemeler yayınların sahip oldukları yazar sayısına eşit olarak bölünmektedir ancak Türkiye adresli akademisyenlerin büyük araştırma gruplarına dahil olmalarını teşvik edebilmek için makale etki puanı 1 ve üzeri olan dergiler için hesaplama yalnızca Türkiye adresli yazarlar dikkate alınarak yapılmaktadır. Bir yazar bir yılda en fazla 10 kez UBYT programına başvurabilir ve bir yayın için asgari teşvik miktarı 500 €, azami teşvik miktarı ise 15.000 モ’dir. Bir yazara verilebilecek teşvik miktarının alt sınırı ise 250 £'dir. Eğer teşvik programına başvuran makale bir doktora tezinden üretilmişse makalenin yazarı olan tez danışmanına yazar başına düşen teşvik miktarının üç katı ödenmektedir. Son olarak UBYT programında Türkiye adresli dergilere pozitif ayrımcılık yapıldığı belirtilmektedir. Bu bağlamda yayıncısı TÜBİTAK olan akademik dergilerin teşvik katsayısı 2, Türkiye adresli dergilerin teşvik katsayısı ise 1,5 olarak tanımlanmışıtır (UBYT S.S.S., 2020).

\footnotetext{
${ }^{2}$ Derginin makale etki puanının hesaplanabilmesi için en az beş yıldır Journal Citation Reports’ta dizinleniyor olması gereklidir.
} 
$\mathrm{Bu}$ çalışmanın temel amacı uluslararası nitelikli yayın sayısını artırmayı hedeflediği belirtilen UBYT programının dergi listesini detaylı olarak inceleyerek disiplin ve ülke bazlı bir analiz gerçekleştirmektir. UBYT tarafından sağlanan dergi sınıflamasının detaylı olarak incelenmesi ile programın güçlü ve zayıf yanlarının ortaya çıkarılması ve buna paralel olarak iyileştirmeler yapılması mümkün olabilecektir. Çalışma kapsamında cevap aranan temel araştırma soruları aşağıda belirtildiği gibidir:

- 2019 yılında hesaplama yönteminde önemli değişikler yapılan UBYT programında 2018 ve 2019 yılları karşılaştırıldığında göze çarpan önemli değiş̧iklikler nelerdir? 2018 listesi ile 2019 listesinin benzerlik ve farkl1lıkları nelerdir?

- UBYT kapsamında teşvik bedellerini belirlemek amacı ile kullanılan makale etki puanı dergilerin yayımlandıkları disiplinlere göre farklılık göstermekte midir?

- UBYT kapsamında belirlenen teşvik sınıfları ile dergilerin yayımlandıkları disiplinler arasında anlamlı bir ilişki var mıdır? Tüm disiplinler teşvik gruplarında yeterince temsil edilmekte midir?

- Yayın teşviki verilen dergilerin yayımlandıkları ülkeler ile teşvik grupları arasında anlamlı bir ilişki var mıdır? Pozitif ayrımcılık yapıldığı belirtilen Türkiye adresli dergilerin teşvik sistemindeki yeri nedir? Türkiye adresli akademisyenlerin yayın için seçtikleri dergilerin ülke gruplarına dağılımı nasıldır?

\section{UBYT Üzerine Yapılan Çalışmalar}

Literatürde UBYT Programının analiz edilmesi üzerine yazılmış çeşitli çalışmalar bulunmaktadır. Bu çalışmaları popüler bilim dergilerinde yayımlanmış yazılar ve bilimsel yayınlar olarak ikiye ayırmak mümkündür. Popüler bilim dergilerinde yer alan yazılardan biri 2010 yılında yayımlanan “Atıf dizinlerinde yayın yapılması nereye kadar desteklenecek?" başlıklı yazıdır (Al, 2010). Yazının çıkış noktası halihazırda en önemli yükümlülüklerinden biri araştırma yapmak ve araştırma sonuçlarını raporlamak olan akademisyenlerin pek çok farklı teşvik sistemi ile desteklenmesinin yaratacağı sorunlara dikkat çekmektir. Zira o yıllarda teşvik olarak verilen meblağların bazı üniversitelerin bir yıllık bütçesinden fazla olduğunun altı çizilmektedir. Bununla birlikte uluslararası yayın sayısını artırması hedeflenen programda en çok desteklenen dergilerin Türkiye menşeili dergiler olması sorgulanmakta ve gelecekteki muhtemel eğilim konusunda uyarılarda bulunulmaktadır. Çalışmanın sonunda bilimsel yayınlar için asıl önemli olan konunun tüm dünyanın erişimine sunulan akademik yayınların bilim dünyasına sağladığı katkılar olduğu önemle vurgulanmaktadır.

2014 yılında ise aynı popüler bilim dergisinde "TÜBİTAK yayın teşvik sistemini değiştirmeli” başlıklı bir yazı kaleme alınmış, UBYT dergi listelerinin tüm disiplinleri doğru şekilde temsil etmemesi sebebiyle akademik yükselme ve teşvik sistemlerinde kullanılmasının yaratacağı problemler üzerine odaklanılmıştır (Yaltırak, 2014). Dergi listelerinde dergilerin seviyesi (sınıfi) belirlenirken oluşacak küçük farkl1lıklar sebebi ile bibliyometrik göstergelerle birlikte uzman değerlendirmelerinin de kullanılması gerektiğini savunan yazar, mevcut sistemin 
devam etmesi halinde gelecekte daha kolay yayın yapılabilen dergilerin tercih edilebileceği ve böylece sistemin yozlaşabileceği konusunda uyarılarda bulunmuştur.

Popüler bilim yazılarının yanında UBYT üzerine yapılmış önemli bilimsel çalışmalar da bulunmaktadır. En kapsamlı yayın hiç şüphesiz 2017 yılında Yaşar Tonta tarafından kaleme alınan "TÜBİTAK Türkiye Adresli Uluslararası Bilimsel Yayınları Teşvik (UBYT) Programının Değerlendirilmesi” başlıklı kitaptır (Tonta, 2017a). Kitabın UBYT'yi hazırlamakla sorumlu olan ULAKBİM Müdürlüğünün talebi üzerine yazılması TÜBİTAK'ın mevcut sistemi iyileştirmeye yönelik girişimlerini göstermesi açısından oldukça önemlidir. Kitapta vurgulanan en önemli bulgu UBYT'nin Türkiye adresli yayın sayısının artışında önemli bir etkisinin olmadığının ortaya koyulmasıdır. ${ }^{3}$ Bunun en temel sebebinin araştırmacıların çoğuna yapılan mikro ödemeler olduğu belirtilmektedir. Çalışma sonunda dergi temelli ölçevlerin dikkatli kullanımından, ortalamanın altındaki dergilere verilen teşviklerin sonlandırılmasına ve sosyal bilimler ile insan bilimlerinin desteklenmesine yönelik olarak yeni politikalar geliştirilmesi gerektiğine kadar farklı boyutlarda öneriler sunulmuş ve programın yeniden tasarlanması gerekliliği önemle vurgulanmıştır.

UBYT üzerine hazırlanan son çalışmalardan biri Tonta ve Akbulut (2019) tarafindan kaleme alınan "Does monetary support increase citation impact of scholarly papers?" (Parasal destek akademik makalelerin atıf etkisini artıır mı?) başlıklı araştırmadır. Performans temelli araştırma fonlama sistemlerinin makalelerin aldıkları atıflara etkisini araştırmayı hedefleyen çalışmada UBYT sistemi ile desteklenen ve desteklenmeyen yayınlar aldıkları atıflar yönünden karşılaştırılmıştır. Sonuçta desteklenen ve desteklenmeyen yayınlar arasında makale başına alınan atıf sayısı açısından büyük benzerlikler olduğu sonucuna ulaşılmıştır. Bu sonuç UBYT programının amacına ulaşmadığı ve mutlaka yeniden gözden geçirilmesi gerektiği şeklinde yorumlanmış ve daha kapsamlı çalışmaların yapılması gerekliliği üzerinde durulmuştur.

2016 ve 2017 yıllarında Journal of Informetrics'te yayımlanan iki makale ise UBYT sistemine farklı açılardan bakmıştır (Yuret, 2016; 2017). 2016 yılında yayımlanan makalede bu çalışmadakine benzer olarak yayın teşvik listesinin tüm disiplinlere eşit mesafede olup olmadığı değerlendirilmiş ve kimya ile ekonomi disiplinlerinde yayımlanan dergilere verilen teşvikler karşılaş̧ırılmıştır. Karşılaştırma sonucunda her bir disiplinin yayın üretim sıklıkları ve verimlilikleri benzer olmadığı için verilen teşviklerin de disiplinlere göre büyük değişiklik gösterdiği kanıtlanmıştır. Örnek olarak seçilen iki alan karşılaşııııldığında kimya alanında yayın yapan Türkiye adresli akademisyenlere ekonomi alanında yapanlara göre 4,3 kat daha fazla ödeme yapıldığı ortaya koyulmuştur (s. 1197). 2017 yılında yayımlanan makalede ise UBYT için 250 € olan alt destek limitinin Türkiye adresli yazarlarca dikkate alınıp alınmadığı ortak yazarlık istatistikleri değerlendirilerek araştırılmıştır. Sonuç olarak Türkiye adresli yayınlara verilecek desteklerde teşvik alt sınırı olmasının yazarların ortak yazarlık tercihlerini değiştirmediği, yani akademisyenlerin UBYT programınca desteklenmeyi hedefleyerek yayın yapmadıkları ortaya koyulmuştur (s. 432).

\footnotetext{
${ }^{3} \mathrm{Bu}$ bulguyu detaylandıran bir çalışma yazar tarafıından 2017 yılında ISSI Konferansında sunulmuştur (Bkz. Tonta, 2017b).
} 
Literatürde UBYT üzerine yapılan çalışmalarda mevcut teşvik sisteminin aksayan yönlerine odaklanarak iyileştirme/düzenleme önerileri getirmiştir. UBYT sisteminin sıkça güncelleniyor olması yapılan bu yayınların karar vericilerce dikkate alındığını ve sistemde iyileştirmeye yönelik adımların atıldığını göstermesi açısından önemlidir. Bu çalışmanın da güncel UBYT listesine disiplinler ve dergilerin yayımlandıkları ülkeler çerçevesinden bakarak alana katkı sağlayacağı düşünülmektedir.

\section{Yöntem}

Araştırma sorularına yanıt verebilmek amacıyla temel olarak 2019 yılı UBYT listesinden yararlanılmıştır. ${ }^{4} 2018$ yılı teşvikleri ile karşılaştırma yapabilmek için ise 2018 y1lı dergi listesi kullanılmıştır. 5,6 2019 yılı listesinde yer alan dergiler 2019 yılı için ULAKBİM tarafından UBYT kapsamında belirlenmiş dört temel teşvik kategorisinde sınıflandırılmış ve 2019 yılına ilişkin tüm analizler bu sınıflama dikkate alınarak gerçekleştirilmiştir. Bu sınıflamada ULAKBİM tarafindan A, B, C ve D harfleri kullanılmakta ve A en düşük ödeme yapılan teşvik grubunu, D ise en yüksek ödeme yapılan teşvik grubunu temsil etmektedir.

TÜBİTAK ULAKBİM uzun yıllar dergilerin sınıflandırılması için çeşitli harf notasyonları kullanmış, her bir değişiklikte kullanılan notasyona ilişkin ilkeler değişiklik göstermiştir (Tonta, 2017a, s. 22-24). Ancak 2013 yılında yapılan değişiklikle harf notasyonu tamamen kaldırılarak dergilerin 0'dan 100'e puanlandığg ve puanlarına göre teşvik miktarlarının belirlendiği bir sisteme geçilmiştir (TÜBİTAK Türkiye Adresli Uluslararası Bilimsel Yayınları Teşvik (UBYT) Programı Uygulama Usul ve Esasları, 2013). 2013 yılına kadar olan tüm sınıflamalarda A harfi üst düzey dergileri temsil ederken D harfi düşük seviyedeki dergiler için kullanılmıştır. Ancak 2019 yılı teşvik esaslarında bu notasyon tersine döndürülmüş, D harfi en yüksek ödeme yapılan dergi grubunu temsil etmeye başlamıştır. Bu bağlamda çalışma kapsamında uygulanan sınıflamanın geçmiş sınıflamalardan farklı olduğu ve en güncel yapıyı sunduğu göz önüne alınmalıdır. İlgili sınıflamanın detayları UBYT sıkça sorulan sorular sayfasında yer almaktadır. ${ }^{7}$

Çalışma kapsamında verileri kullanılan 2018 yılı dergi listesi 2017 yılı UBYT uygulama esasları dikkate alınarak hazırlanmıştır. 2018 listesinde tüm dergiler için 0'dan 100'e dergi puanları belirlenmiş ve ödemeler bu değerlere göre belirlenmiştir (TÜBİTAK Türkiye Adresli Uluslararası Bilimsel Yayınları Teşvik (UBYT) Programı Uygulama Usul ve Esasları, 2017). ULAKBİM uzmanlarınca teşvik usul ve esasları belgesinde yer alan formüllere göre belirlenen dergi puanları ile bu puanların teşvik karşılıkları TÜBİTAK ULAKBİM web sitesinde sunulmaktadir.

UBYT politikasında 2019 yılında harf notasyonuna dayalı bir sinıflandırma mevcut iken 2018 yılında olmaması sebebi ile çalışma kapsamında iki listeyi birbiri ile karşılaştırabilmek ve

\footnotetext{
${ }^{4}$ http://cabim.ulakbim.gov.tr/wp-content/uploads/sites/4/2019/05/UBYT_2019_Y\%C4\%B11\%C4\%B1_Dergi-_Listesi.xlsx

${ }^{5} \mathrm{http} / / /$ cabim.ulakbim.gov.tr/wp-content/uploads/sites/4/2018/07/2018-UBYT-Dergi-Listesi.xlsx

${ }^{6} 2018$ yılı dergi listesinde Archaeology in Oceania adlı dergi iki kez anılmakta ve farklı teşvik bedelleri belirtilmektedir. İlgili dergide Türkiye adresli herhangi bir yayın olmadığı için listeden çıkarılmıştır.

${ }^{7}$ https://cabim.ulakbim.gov.tr/anasayfa/ubyt/ubyt-s-s-s/
} 
ilk araştırma sorusuna cevap verebilmek zordur. Bunu sağlayabilmek amacı ile 2019 yılı için TÜBITAK ULAKBİM tarafından gerçekleştirilen sınıflamaya benzer bir sinıflama 2018 yılı listesine uygulanmıştır. Bölümlemede dergilere verilen teşvik miktarları dikkate alınmış, en yüksek miktarda teşvik verilen dergiler D, 5000 £’ye kadar destek verilen dergiler C, 2500 モ’e kadar desteklenen dergiler B ve diğer dergiler A sınıfında kabul edilmiştir. Elbette bu sınıflama TÜBITTAK ULAKBIM tarafından UBYT politikası içinde belirlenmiş bir sınıflama olmadığından resmi bir nitelik taşımamaktadır ancak dergilerin aldıkları teşvik miktarları üzerinden muhtemel konumlarını temsil etmektedir. Tablo 1 araştırma kapsamında yer alan dergilerin sınıflara dağılımını ve teşvik kriterlerini göstermektedir.

Tablo 1

2018 ve 2019 yılı dergi listeleri için belirlenen sinıflama aralıkları

\begin{tabular}{|c|c|c|c|c|}
\hline & & Teşvik miktarı & & Teşvik kriter \\
\hline Dergi sınıfi & 2018 & 2019 & 2018 (Dergi puanı) & 2019 (MEP) \\
\hline Teşvik D & $7500 €$ & $15.000 €$ & 100 & $3,0+$ \\
\hline Teşvik C & $7499 €-5000 €$ & $10.000 €$ & $83,8-99,9$ & $2,0-2,9$ \\
\hline Tesvik B & $4999 €-2500 €$ & $7500 €$ & $60,6-83,7$ & $1,5-1,9$ \\
\hline Teşvik A & $500 €-2499 €$ & $500 €-7499 €$ & $0-60,5$ & $0,1-1,4$ \\
\hline
\end{tabular}

Her bir dergide 2018 ve 2019 yıllarında yapılan Türkiye adresli yayınlara (makale ve derleme) ilişkin sayısal bilgileri elde edebilmek amacıyla Web of Science'ın üç temel dizini olan SCI, SSCI ve A\&HCI'da $A D=($ Turkey OR Turkiye) $A N D P Y=2018$ ve $A D=$ (Turkey OR Turkiye) $A N D P Y=2019$ şeklinde iki sorgu gerçekleştirilmiş, ardından makale ve derlemeler ayrı ayrı filtrelenerek dört farklı veri setine erişilmiştir. ${ }^{8}$ Bu noktada makalenin yanında farklı bir türde de sınıflanmış yayınlar (bildiri veya kitap kritiği gibi) veri setinin dışında tutulmuştur. Elde edilen sonuçlar arasından yayın yapılan dergilere ilişkin sıklık bilgilerine erişmek amacıyla Web of Science'ın analyze results (sonuçları analiz et) özelliği kullanılmıştır. Web of Science içeriğinde yer alan dergilerdeki Türkiye adresli yayın sıklıkları txt formatında elde edildikten sonra UBYT dergi listesi ile çakıştırılmış ve veri setine eklenmiştir.

Web of Science veri tabanında dizinlenen her bir dergi 255 konu kategorisinden en az birinde yer bulmakta ve konusal sınıflama Web of Science tarafından gerçekleştirilmektedir. Çalışma kapsamında bu 255 konu kategorisinde yayımlanmış dergileri temel konulara göre sınıflayabilmek amacı ile OECD sınıflama şeması kullanılmıştır ("Clarivate Analytics", 2012). Bir derginin birden fazla konu alanına girmesi mümkündür. Bu dergiler çalışma içinde "çok disiplinli dergiler" başlığ 1 altında anılmıştır. Sonuç olarak tüm dergiler doğa bilimleri, mühendislik ve teknoloji, tıp ve sağlık bilimleri, tarım ve veterinerlik, sosyal bilimler, sanat ve insan bilimleri ile çok disiplinli kategorilerinde sınıflandırılarak değerlendirilmiştir.

Dergilerin hangi ülkelerde yayımlandığı bilgisi çeşitli karşılaştırmaların yapılabilmesi için önemlidir. Bu bağlamda Web of Science içeriğinde yer alan tüm dergileri yayıncı detaylarıyla listeleyen Web of Science Master Journal List (Web of Science dergi listesi) kullanılarak yayıncı

\footnotetext{
${ }^{8}$ Sorgu tarihi: 12 Nisan 2020. Bu tarihten sonra dizinlenen ilgili yıllara ait yayınlar çalışma kapsamında değerlendirilememiştir. İndekslerde birden fazla doküman tipinde sinıflanan yayınlar (hem makale hem de bildiri [proceeding] veya erken görünüm [early access] olarak yayınlanan makaleler gibi) araştırma kapsamından çıkarılmıştır.
} 
adreslerine erişilmiştir ("Master Journal List”, 2020). Adreslerden ülke bilgileri çekildikten sonra UBYT listesi ile çakıştırılmış ve ülke bilgileri veri setine eklenmiştir. Ülkelerin sınıflandırılması için ise Dünya Bankası'nın geliştirdiği bölge sınıflaması kullanılmıştır (“The World Bank”, 2019). Çalışma kapsamında Türkiye adresli dergilere ilişsin araştırma soruları bulunduğundan Türkiye adresli dergiler herhangi bir gruba eklenmemiş, farklı bir sınıf olarak değerlendirilmiştir.

Tüm verilerin derlenmesinin ardından istatistiksel analizler ve kutu grafikleri için R altyapısı ile çalışan R Commander yazılımı ile R Commander eklentisi olan KMggplot2 kullanılmıştır. Harita görselleştirmesi için ise StatPlanet yazılımından yararlanılmıştır.

\section{Bulgular}

\section{8 ve 2019 Yılı UBYT Dergi Listelerine Genel Bakış}

Şekil 1'de 2018 ve 2019 yıllarında Web of Science'ın çekirdek dizinlerinde yer bulmuş Türkiye adresli makale ve derleme sayıları ile ilgili yıllara ait UBYT listelerine ilişkin detaylı istatistikler yer almaktadır. Buna göre 2018 ve 2019 yılları dergi listeleri arasındaki en önemli farklar hesaplama yönteminin değişmesi sonucu desteklenen dergi sayısının azalması ${ }^{9}$ ve en üst düzey addedilen dergilere verilen parasal desteğin bir önceki yıla göre iki katına çıkarılmasıdır. Ancak 2018 yılında dergi puanı 100 olan ve en yüksek teşvik miktarı ile desteklenen (7500 £) dergi sayısı 781 iken (tüm dergilerin \%6’s1), 2019 yılında en yüksek kalemden (15.000 $€$ ) desteklenen dergi sayıs 385 'tir (tüm dergilerin \%3,7'si). Yani tavan miktardan ödeme alan dergi sayısı azaltılmış ancak ödeme miktarı iki katına çıkarılmıştır.

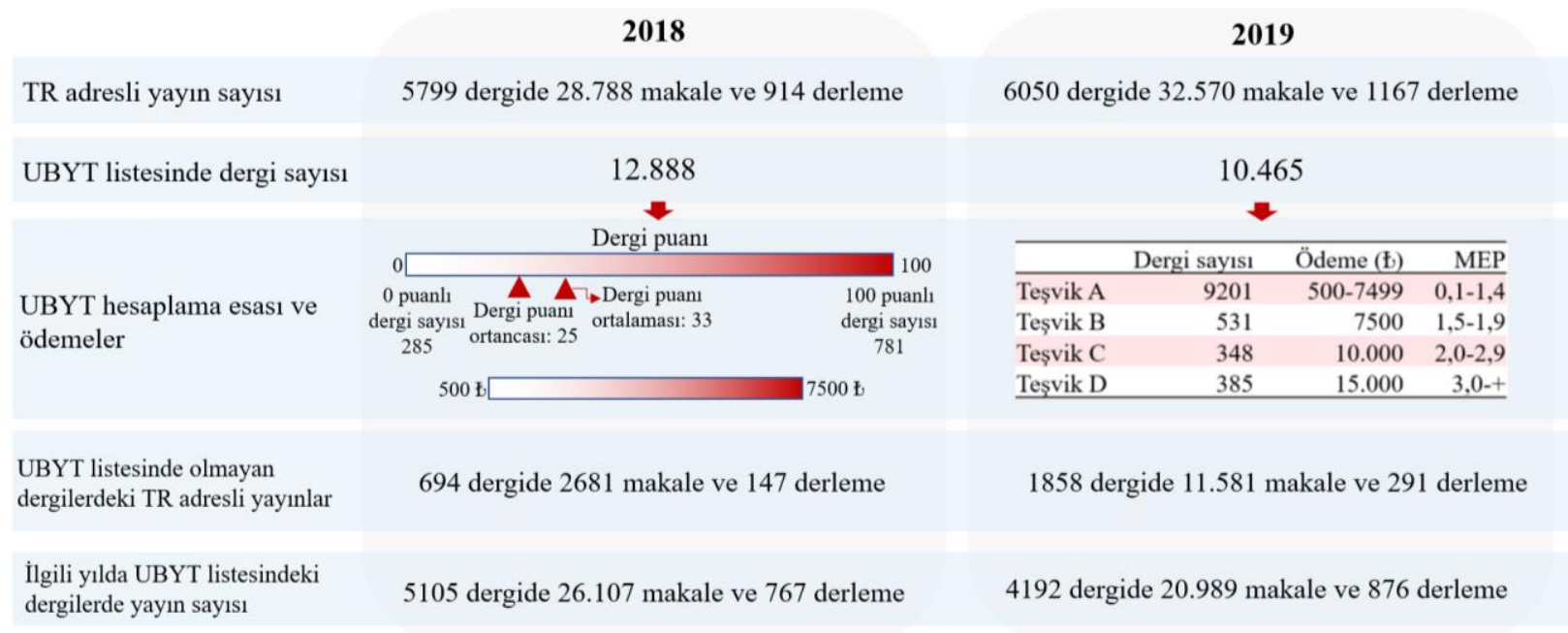

Şekil 1. 2018 ve 2019 yıllarında Web of Science dizinlerinde yer almış Türkiye adresli yayın sayıları ile UBYT listelerinin karşılaştırmalı analizi

Yine Şekil 1 incelendiğinde 2019 yılında 2018 yılına göre daha fazla yayın yapılmış olmasına rağmen ${ }^{10} 2018$ yılında yapılan yayınların daha fazla kısmının UBYT tarafından desteklenen dergilerde yer bulduğu görülmektedir. Bu da teşvik programınca desteklenen dergi

\footnotetext{
${ }^{9} 2018$ yılında desteklenen dergi sayıs 2019 yılı dergi sayısından 2423 fazladır.

$10+3782$ makale ve +253 derleme
} 
sayılarının azalması sonucu beklenen bir durumdur. Bununla birlikte her iki yılda da Türkiye adresli yayınlar UBYT listesindeki dergilerin \%40'1nda yer bulmuştur. Tablo 2 her bir sınıfta yer alan dergilerde yayımlanmış Türkiye adresli makale ve derleme sayılarını detaylı olarak göstermektedir. Tablodan da görülebileceği üzere Türkiye adresli yayınların önemli bir bölümü A sınıfında yer alan dergilerde yer bulmuştur. Bu sınıfta yer alan dergi sayısının azalması ile yayın sayısının da düştüğü gözlenmektedir. Bu noktada iki yılın listelerine karşılaştırmalı bakmak ve listelerin benzerlik/farklılıklarının izlenmesi önemlidir. Zira uygulanmakta olan sistemin tamamıyla değiştirilmesinin (dergi puanı sisteminden makale etki puanına) ortaya çıkardığı değişikliğin boyutlarının bilinmesi ve bunun potansiyel etkilerinin saptanması önemlidir.

Tablo 2

2018 ve 2019 yılı teşvik listeleri ve TR adresli yayın sayıları

\begin{tabular}{lrrrrrr}
\hline \multicolumn{1}{l}{$\begin{array}{l}\text { Teşvik } \\
\text { grubu }\end{array}$} & $\begin{array}{r}\text { Dergi } \\
\text { sayı1 }\end{array}$ & $\begin{array}{r}\text { Makale } \\
\text { sayıs1 }\end{array}$ & $\begin{array}{r}\text { Derleme } \\
\text { sayı1s1 }\end{array}$ & $\begin{array}{r}\text { Dergi } \\
\text { sayıs1 }\end{array}$ & $\begin{array}{r}\text { Makale } \\
\text { sayıs1 }\end{array}$ & $\begin{array}{r}\text { Derleme } \\
\text { sayı1s1 }\end{array}$ \\
\hline D & 781 & 538 & 42 & 385 & 462 & 28 \\
C & 373 & 437 & 18 & 348 & 263 & 31 \\
B & 1043 & 1499 & 56 & 531 & 519 & 49 \\
A & 10.691 & 23.635 & 651 & 9201 & 19.745 & 768 \\
\hline
\end{tabular}

2018 y1lı listesinde yer alan ancak 2019 yılı listesinde hesaplama yönteminin değiştirilmesi veya başka sebeplerle çıkarılmış dergi sayısı 2594'tür. Bu dergilerin yalnızca biri D sınıfında dizinlenmektedir. 2018 yilında listede olan ve 7500 € ile desteklenen (100 puan), ancak 2019 yılında listeden çıkarılan Progress in Inorganic Chemistry dergisinin listeden çıkarılma sebebi ilgili kaynağın JCR 2017 ve 2018'de dizinlenmiyor oluşudur. Listeden çıkarılan dergilerden beşi ise B sinıfında yer almaktadır. Bu dergilerin dördü benzer şekilde JCR 2017 ve 2018 listelerinde yer almamaktadır. Ancak JCR 2018'de yer alan ve makale etki puanı 0,30 olan Ciencia E Agrotecnologia adlı dergi de (2018 yılı teşvik miktarı: 2610 £) 2019 listesinde yer almamaktadır. İlgili altı dergide de 2018 yılında hiç Türkiye adresli yayın yapılmamıştır. 2019 listesine dâhil edilmeyen kalan 2588 derginin tamamı A sinıfindadır. 2018 y1lı listesinde yer alıp 2019 y1lı listesinde yer bulamamış 2594 derginin dergi başına düşen ortalama teşvik miktarı 559 €'dir (ortanca: 509 £). Bu dergilerin ortalama dergi puan1 9,5'tir (ortanca: 7,6). Listelerdeki en önemli farklardan biri 2018 yılında Türkiye adresli 587 makale/derleme yayımlayan ve 500 € ile desteklenen Fresenius Environmental Bulletin dergisinin 2019 y1l listesinde yer almiyor oluşudur. 2019 yılı listesine dâhil edilmeyen dergilerde 2018 yılında yapılan toplam yayın sayısı 7866'dır. Tüm bunlar Tonta tarafından belirtilen (2017, s. xviii) ve araştırmacıların çoğuna yapılan mikro ödemeler sebebi ile kaynakların ortalamanın oldukça altındaki çalışmaları teşvik etmek için kullanıldığına yönelik bulgusunun ULAKBİM tarafından dikkate alındığını ve düzeltmeye yönelik faaliyette bulunulduğunu göstermesi açısından önemlidir. Ancak Fresenius Environmental Bulletin dergisinde UBYT dergi listesinde olmamasına rağmen 2019 yılında da 540 Türkiye adresli makale yayımlanması yazarların UBYT Programını hedefleyerek makale yazmıyor oluşunu gösteriyor olabilir. Bu bulgu Yuret'in bulgularını (2017, s. 432) destekler niteliktedir. Ancak kesin bir çıkarımda bulunmak zordur, çünkü 2019 yılı UBYT dergi listesi 2019 yılının Mayıs ayında duyurulmuş, yani 2019 yılında ilgili derginin listede yer alıp almayacağı Mayıs 
ayında açıklandığından bu durumun yazar tercihlerini etkileyip etkilemediği konusunda çıkarım yapmak yanıltıcı olabilir. İlerleyen yıllarda bu dergide yayımlanan Türkiye adresli makale sayısının değişimi izlenerek bir çıkarımda bulunmak mümkün olabilecektir.

2018 listesinde yer almayan ancak 2019 yılinda listeye eklenen dergi sayısı ise 171'dir. Bu dergilerin listeye eklenme sebepleri çeşitlilik göstermektedir ve bu çeşitlilik Şekil 2'de sunulmaktadır. 2019 yılında bu 171 derginin 60'ında 233 Türkiye adresli yayın yer bulmuştur. Listeye yeni eklenen dergilerden en çok Türkiye adresli makale yayımlayan dergi Türkiye menşeili Turkish Journal of Physical Medicine and Rehabilitation adlı dergidir (38 yayın).

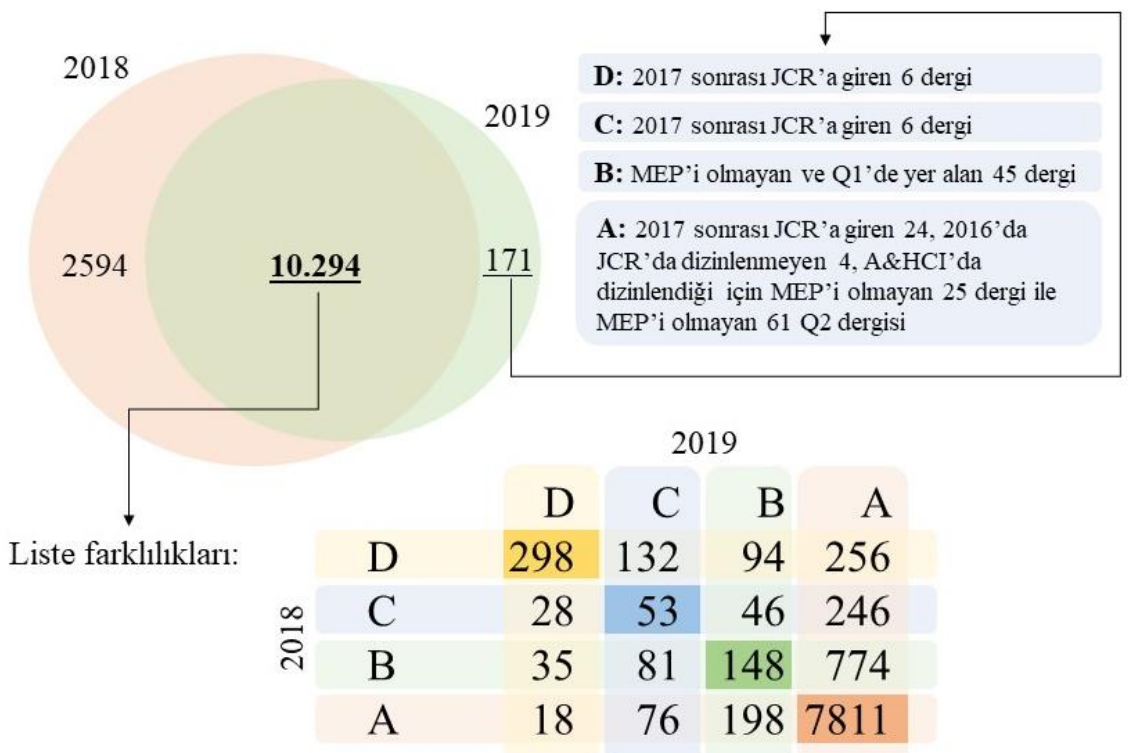

Şekil 2. 2018 ve 2019 yılı listelerinin karşılaştırmalı analizi

Tablo 2'de sunulan verilere bakıldığında liste farklılıklarının düşük puanlı dergilerin listelerden çıkarılması kaynaklı olduğu gibi bir çerçeve çizilebiliyor olmasına rağmen dergi listelerine daha detaylı bakıldığında hesaplama yönteminin değiştirilmiş olmasının 2018 ve 2019 yıllarında sunulan dergi listelerini ve bu listelerde yer alan dergilere verilen teşvikleri önemli oranda etkilediği görülmektedir. Örneğin, 2018 yılında en üst kademeden desteklenen ve üst düzey kabul edilen 256 dergi 2019 listesinde A sınıfında yer almıştır ve 2018 yılında bu dergilere 7500 € teşvik verilirken 2019 yılında dergi başına düşen ortalama teşvik miktarı 4408 €'dir (ortanca: 4625 £). Benzer şekilde 2018 yılında en düşük kademede sınıflanan ve ortalama 1532 € (ortanca: 1327 £) teşvik verilen 18 dergi 2019 yllında 15.000 £ desteklenen dergiler grubuna dahil edilmiştir. Bu değişimin sebebi elbette hesaplama yönteminin değiştirilmiş olmasıdır ancak bir yılda yaşanan bu büyük değişimin yazarlarda ve karar vericilerde dergi temelli ölçevlerle belirlenmiş "kalite" algısına yönelik olumsuz etkileri olabileceği göz önünde bulundurulmalıdır. Zira düşük seviyede olduğu kabul edilen bir derginin çok zaman geçmeden üst düzey dergilerden biri olarak addedilmesi dergi temelli göstergelere dayanan sistemlerin küçük değişikliklerden önemli oranda etkilenebileceğini göstermesi açısından oldukça önemlidir. 
Sonuç olarak 2018 ve 2019 yllı listelerinin birbirlerinden oldukça farklı olduğu ve UBYT programındaki değişikliklerin UBYT dergi listesinin çehresini değiştirdiği açıktır. Bu noktada 2019 yılında kullanılan listeye yakından bakmak, disiplin ve dergilerin yayımlandıkları ülkelere dayanan farklılıkları ortaya koyarak teşvik kapsamında üst düzey atfedilen dergilerin herhangi bir disipline veya ülke dergisine avantaj sağlayıp sağlamadığının anlaşılması önemlidir.

\section{Yılı Listesinde Disiplin Temelli Farklılıklar}

Çalışmanın bu bölümünde MEP değerinin ve bu değerlere bağlı dergi gruplarının disiplinlere göre farklılık gösterip göstermediğini araştırmak amacı ile çeşitli analizler gerçekleştirilmiş ve sonuçları sunulmuştur.

\section{Makale Etki Puanları ve Teşvik Gruplarının Disiplin Temelli Değerlendirilmesi}

Dergi temelli ölçevlerin araştırma perfromans değerlendirmelerinde kullanımının sakıncalarından giriş bölümünde kısaca bahsedilmişti. 2018 yılına kadar UBYT programında dergiler etki faktörü, 5 yıllık etki faktörü, makale etki puanı ve ortalama atıf yarı yaşamı gibi çeşitli dergi temelli göstergeler kullanılarak yapılan hesaplamalar ile sinıflandırılmaktaydı. Ancak 2019 yılına gelindiğinde istisnai durumları olmakla birlikte temel değerlendirme ölçevi makale etki puanı olarak kabul edildi. Bu değişiklik Tonta'nın (2017, s. xix) yaptığı hesaplamalar sonucunda makale etki puanının özgün anlamını kaybettiğine ilişkin değerlendirmesinin ULAKBİM tarafindan dikkate alındığını ve iyileştirmeye gidildiğini göstermesi açısından önemlidir. Bu noktada çalışma kapsamında teşvik mekanizmasında makale etki puanının kullanılmasının herhangi bir disipline avantaj ya da dezavantaj sağlayıp sağlamadığı test edilmiştir.

Makale etki puanlarının dergilerin konu kategorilerine göre değişiklik gösterip göstermediğine yönelik olarak yapılan analizde konu kategorilerinin makale etki puanına etkisi olduğu sonucuna ulaşılmışıtır $\left(\chi^{2}{ }_{(6)}=3487,994 ; p<0,001\right)$. Kruskal Wallis testi sonuçlarına göre bir derginin yayımlandığı disiplin ile makale etki puanı ortalamaları arasında anlamlı bir ilişki vardır. Farkın hangi sınıflardan kaynaklandığını anlamak üzere yürütülen Mann Whitney U testi sonuçları Ek 1'de sunulmaktadır. İkili yapılan testlerin sonucuna göre makale etki puanları birbirine benzeyen, yani puan ortalamaları arasında anlamlı bir fark olmayan iki disiplin doğa bilimleri ile tıp ve sağlık bilimleridir. Diğer tüm alanlarda disiplinlerin makale etki puanları farklılık göstermektedir.

Teşvik edilen dergilerin çalışma alanlarına dağılımına bakıldığında ise 2019 teşvik listesinde en fazla yer bulan kategorinin 2455 dergisiyle tıp ve sağlık bilimleri alanı olduğu görülmektedir. Tıp ve sağlık bilimleri alanında desteklenen dergilerin 2078'i MEP dikkate alınarak yapılan sınıflamada A, 153'ü B sinıfında yer almaktadır. C ve D sinıflarında ise 112'şer dergi bulunmaktadır. Tıp ve sağlık bilimlerini 2179 dergisi ile doğa bilimleri alanı takip etmektedir. Doğa bilimlerinde 1790 dergi A, 161 dergi B, 96 dergi C ve 132 dergi D sınıfında yer almaktadır. 1991 dergi birden fazla konu kategorisinde sınıflanmaktadır. Bu dergiler Şekil 2'de "çok disiplinli" başlığı ile temsil edilmektedir. Bu 1991 derginin 1775'i A, 100'ü B, 57'si C ve 59'u D sınıfında yer almaktadır. Mühendislik ve teknoloji konu kategorisinde 610 dergi bulunmaktadır ve bu 
dergilerin 556'sı A grubunda sinıflanmaktadır. Benzer şekilde tarım ve veterinerlik konusunda kapsanan dergi sayıs1 168 olup bu dergilerin 162'si A grubundadır. Tarım ve veterinerlik alanında üst düzey kabul edilen D sınıfı dergi bulunmamaktadır. Sosyal bilimler ile sanat ve insan bilimlerinin dergi sayısı hemen hemen aynıdır. Sanat ve insan bilimleri dergileri için UBYT kapsamında sabit ücret politikası olduğundan dolayı sanat ve insan bilimlerinin tüm dergileri A sınıfında yer almaktadır. Teşvik gruplarına bakıldığında MEP testi sonucunu destekler nitelikte olarak D sınıfında doğa bilimleri ile tıp ve sağlık bilimlerinin baskın olduğunu izlemek mümkündür (bkz. Şekil 2). Teşvik sınıfları ile disiplinler arasındaki ilişkiyi anlamak üzere uygulanan $\chi^{2}$ testi sonucuna göre teşvik sınıfları ve bu sınıflarda yer alan konu kategorileri arasında istatistiksel olarak anlamlı bir ilişki saptanmıştır $\left(\chi_{(18)}^{2}=347,891 ; p<0,001\right)$. Yani, UBYT programında teşvik verilen dergilerin yer aldığı sınıflar disiplinlere göre değişiklik göstermektedir. Bu durumda UBYT listesinde disiplinlerin her teşvik sınıfında eşit düzeyde temsil edilmediğini görmek mümkündür.

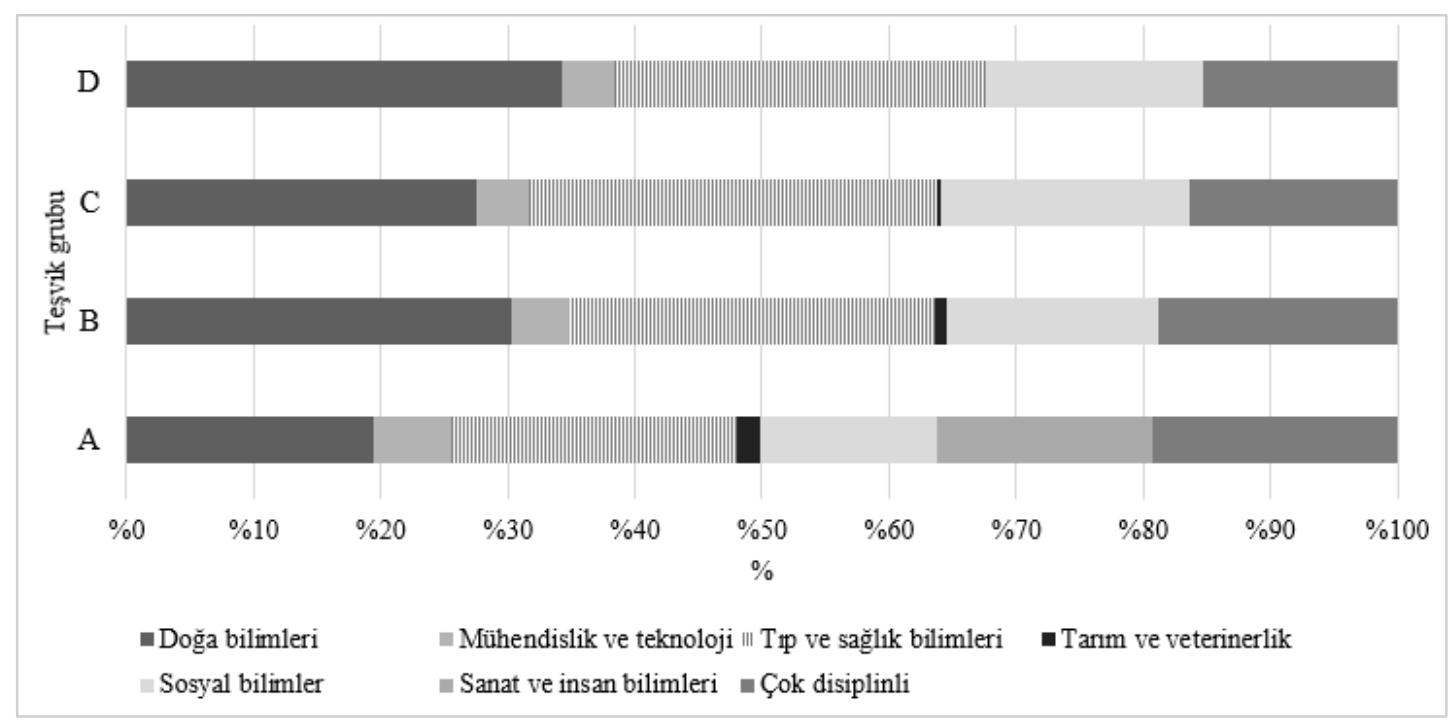

Şekil 3. Yayına teşvik edilen dergilerin OECD konu kategorilerine dăğlımı

Disiplinlerin yayın yapma sıklıklarının farklı oluşu bazı disiplinlerin teşvik mekanizmalarından yararlanma şansını artırmakta bazılarının ise azaltmaktadır. Bunu anlamak amacı ile yürütülen analizin sonuçları Tablo 3'te gösterilmektedir. Buna göre en dezavantajlı grupların sanat ve insan bilimleri ile tarım ve veterinerlik disiplinlerinde çalışanlar olduğu görülmektedir. Tarım ve veterinerlik disiplininde yer alan dergi sayısı oldukça azdır ve bunun yanında dergi başına düşen teşvik miktarları diğer disiplinlere göre oldukça düşüktür. Dergi alternatifi bulma ve yayına teşvik almada yaygın bilinenin aksine UBYT sisteminde sanat ve insan bilimleri yanında mühendislik ve teknoloji ile tarım ve veterinerlik alanlarının da dezavantajlı olduğu görülmektedir. 
Tablo 3

Disiplinlere göre teşviklerin ve yayınların dağılımı (2019 yılı)

\begin{tabular}{lrrrr}
\hline Disiplin & $\begin{array}{r}\text { Toplam TR } \\
\text { adresli yayın } \\
\text { sayısı }\end{array}$ & $\begin{array}{r}\text { Dergi başına } \\
\text { ortalama teşvik } \\
\text { miktarı (£) }\end{array}$ & $\begin{array}{r}\text { Dergi başı̇a } \\
\text { teşvik miktarı } \\
\text { ortancası (£) }\end{array}$ & $\begin{array}{r}\text { Toplam } \\
\text { dergi sayıs1 }\end{array}$ \\
\hline Sosyal bilimler & 1356 & 4321 & 3292 & 1501 \\
Doğa bilimleri & 5503 & 4596 & 3445 & 2179 \\
Çok disiplinli & 4783 & 3974 & 3120 & 1991 \\
Tip ve sağlık bilimleri & 6810 & 4498 & 3550 & 2455 \\
Mühendislik ve teknoloji & 2411 & 3642 & 2920 & 610 \\
Sanat ve insan bilimleri & 622 & 2055 & 2000 & 1561 \\
Tarım ve veterinerlik & 380 & 2667 & 2225 & 168 \\
\hline
\end{tabular}

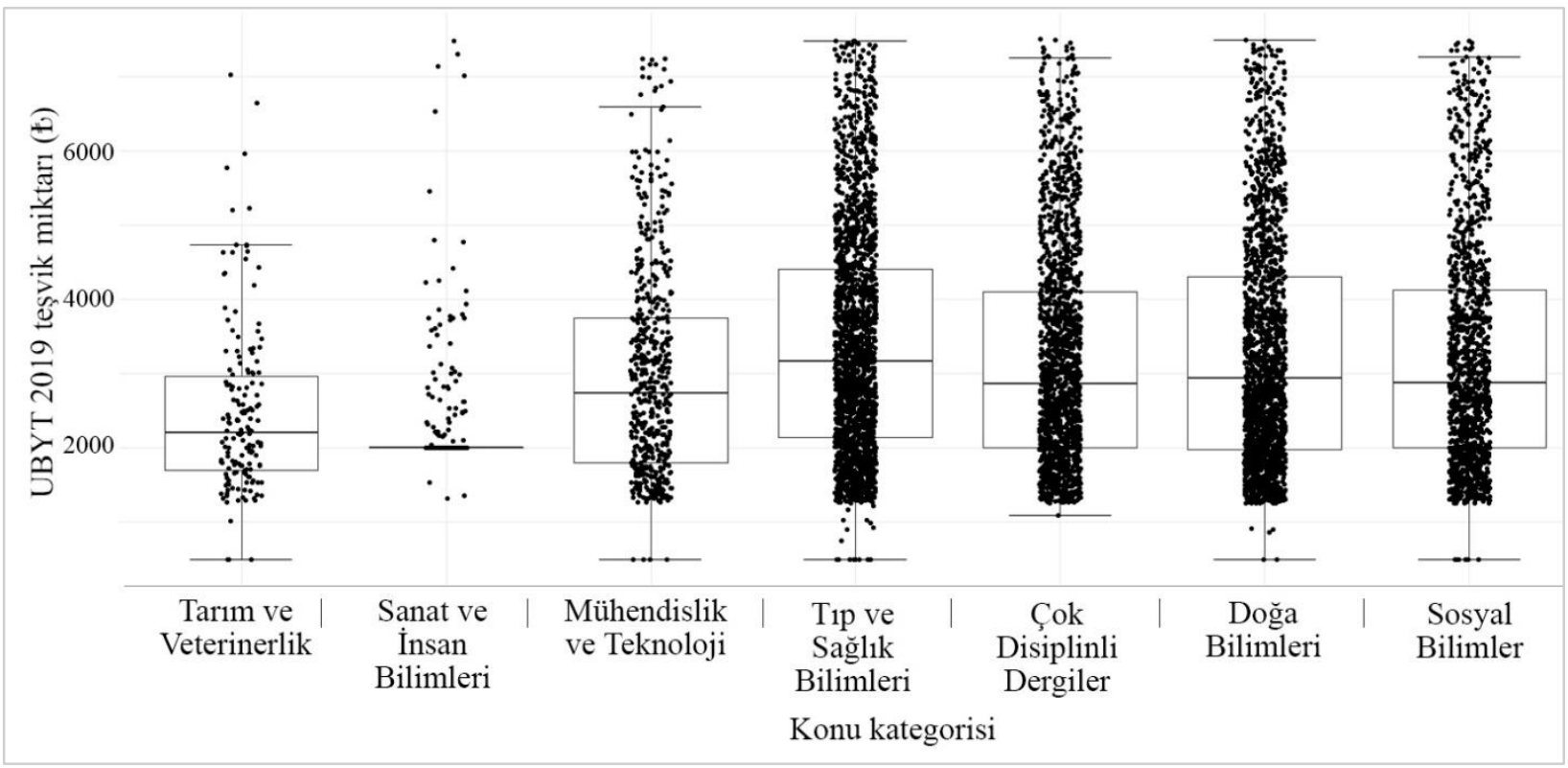

Şekil 4. A sınıfında yer alan dergilerin disiplinlere göre dağılımı

$\mathrm{Bu}$ noktaya kadar olan tüm istatistikler Türkiye adresli araştırmacıların sıklıkla $\mathrm{A}$ grubu dergilerinde yayın yaptıklarını ortaya çıkarmaktadır. Bu durum A grubu dergilere daha detaylı bakma gerekliliğini doğurmaktadır. A grubunun disiplinlere dağılımı Şekil 4'te gösterilen kutu grafiği ile sunulmaktadır. Kutu grafikte üst çizgiler maksimum değeri, orta çizgi ortancayı, alt çizgi ise minimum değeri temsil eder. Her bir çeyrek dilim bir çizgi ile ayrılmıştır ve kutu ikinci ve üçüncü çeyreği göstermektedir. Grafikte yer alan noktalar ise dergileri temsil etmektedir. $500 €$ ile 7499 € arasında değişen miktarlarda teşvik verilen A grubunda tıp ve sağlık bilimleri, çok disiplinli dergiler, doğa bilimleri ve sosyal bilimler dergileri sayısal olarak üstün oldukları kadar geniş bir yelpazede teşvik edilmişlerdir. Öte yandan UBYT politikası gereğince A\&HCI dergilerinin tamamına makale etki puanı olmadığı için 2000 £ destek verilse de bazı dergiler SSCI'da da dizinlendiği için 2000 モ’nin üstünde veya altında destek alabilmektedirler. Öte yandan SSCI'da dizinlenen Linguistics, History, History and Philosophy of Science ve Ethics kategorilerinin OECD sınıflamasında sanat ve insan bilimleri altında değerlendiriliyor oluşu grafikte 2000 ₹ dışında meblağların da yer almasına sebep olmuştur. Bu noktada 1561 sanat ve insan bilimleri dergisinin 
1494'ünün 2000 モ ile teşvik edildiği görülmektedir. A grubunda yer alan mühendislik ve teknoloji dergileri ise sıklıkla 1800 € ila 3800 € arasında teşvik edilmektedir. Tarım ve veterinerlik alanının dezavantajlı durumu bu şekilden de net bir şekilde görülebilmektedir.

\section{Teşvik Verilen Dergilerin Yayımlandıkları Ülkeler}

Yayın için verilen teşviklerin hangi ülkelere ait dergilere yönelik olarak yapıldığını anlamak amacı ile gerçekleştirilen analizde Şekil 5'te gösterilen haritaya ulaşılmıştır. En çok teşvik verilen dergilerin yayımlandıkları ülkenin Web of Science'da da en çok dergiye sahip olan ülke Amerika Birleşik Devletleri olması şaşırtıcı değildir zira teşvik listeleri Journal Citation Reports veri tabanının sunduğu veriler kullanılarak hazırlanmaktadır. ABD'nin 4038 dergisi (UBYT kapsamındaki dergilerin \%38,6'i) UBYT kapsamında desteklenmektedir. ABD'yi 2685 dergi ile İngiltere, 872 dergi ile Hollanda ve 616 dergi ile Almanya takip etmektedir. Puan hesaplama politikasında Türkiye adresli dergilere pozitif ayrımcılık yapıldığı belirtilen UBYT'de teşvik verilen Türkiye adresli dergi sayısı ise 64'tür (\%0.6). Teşvik listesinde ilk 10 sırada 6 Avrupa ülkesi yer almaktadır. Bunun yanında Japonya 162 dergisi ile yedinci, Çin 141 dergisi ile sekizinci ve Avustralya 133 dergisi ile dokuzuncu sıradadır.

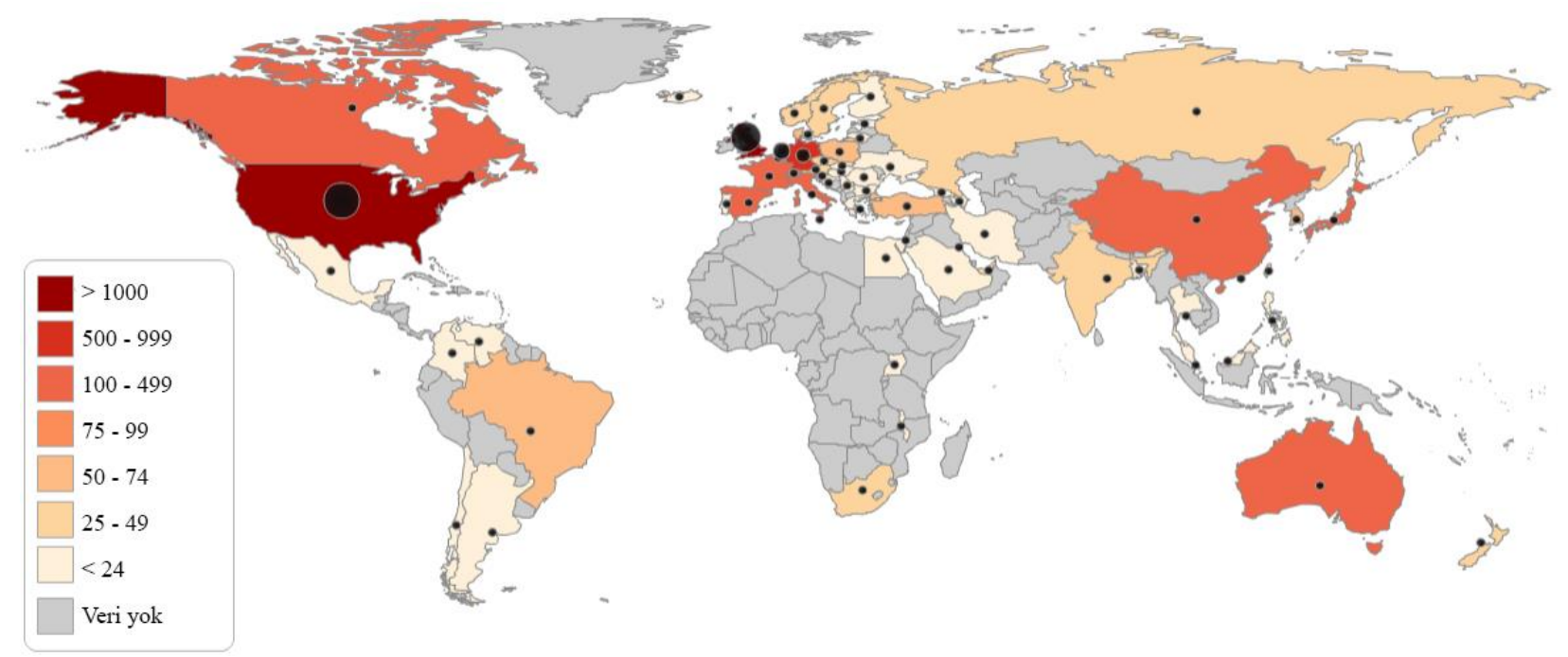

Şekil 5. Teşvik verilen dergilerin yayımlandıkları ülkeler (etkileşimli harita için: http://yunus.hacettepe.edu.tr/ Ztaskin/UBYT/StatPlanet.html $)^{11}$

Teşvik verilen dergilerin ülke gruplarına dağılımına bakıldığında ise Şekil 6'da gösterilen grafiğe ulaşılmıştır. Buna göre üst düzey dergileri içeren D grubunun \%98'ini Kuzey Amerika dergileri ile Avrupa/Merkez Asya dergileri oluşturmaktadır. C grubunda da durum hemen hemen aynıdır. Son grupta Kuzey Amerika dergilerinin baskınlığı yerini Avrupa ve Merkez Asya dergilerine bırakmıştır. Pek çok ülke grubunun yalnızca son teşvik grubunda yer aldığını söylemek mümkündür.

\footnotetext{
${ }^{11}$ Etkileşimli haritada her bir ülkenin dergileri teşvik sınıflarına göre de detaylı olarak listelenmektedir. Google Chrome flash uygulaması çalıştırmak için izin isteyebilir. Bu durumda eklentinin çalışmasına izin verildiği takdirde etkileşimli sayfa açılacaktır.
} 


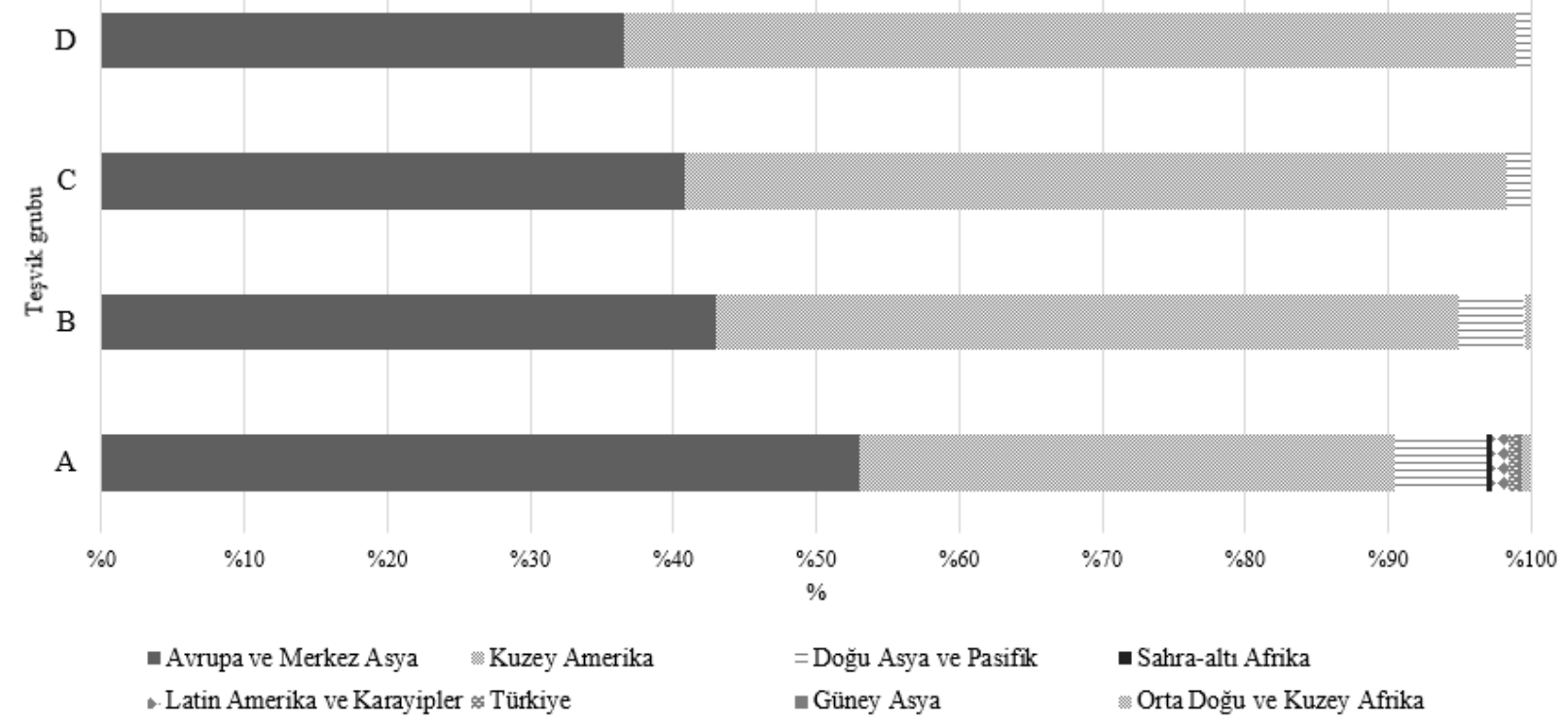

Şekil 6. Her bir teşvik grubunda yer alan dergilerin yayıncı ülkelere göre dağılımı

Ülke gruplarına verilen teşvik miktarları dikkate alınarak bir kutu grafik hazırlandığında ise Şekil 7'de gösterilen grafiğe ulaşılmıştır. Grafikten de açıkça görüleceği üzere 15.000 モ ve 10.000 E’'lik teşviklerin neredeyse tamamı Kuzey Amerika ve Avrupa/Merkez Asya ülkelerine ait dergilere verilmektedir. Bunun yanında az sayıda da olsa Doğu Asya ve Pasifik ülkelerinden de üst grupta teşvik alan dergiler vardır. Dergi sayıları kutu grafik üzerindeki noktalardan da izlenebileceği gibi belirli ülke gruplarında yoğunlaşmıştır. Türkiye adresli dergiler ile Afrika dergilerinin tamamı A grubundan teşvik almaktadır. Türkiye adresli yayınların ülke gruplarına dağılımına bakıldığında yayınların \%50'sinin Avrupa ve Merkez Asya dergilerinde yer bulduğu görülmektedir. Dergi başına düşen yayın sayılarının ülke gruplarına dağılımına bakıldığında ise UBYT kapsamında listelenen Türkiye adresli bir dergide ortalama 42,8 makale yayımlandığı görülmektedir. Bunu 3,4 ile Güney Asya ülkelerine ait dergiler takip etmektedir.

Çalışmanın bulgular bölümünün başında derginin yayımlandığı disiplin ile sahip olduğu etki puanı arasında anlamlı bir ilişki olduğu sonucuna ulaşılmıştı. Benzer bir test (Kruskal Wallis) dergi ülke grubu ile etki puanı arasında gerçekleştirildiğinde de anlamlı bir ilişki olduğu sonucuna ulaşılmıştır $(\chi 2(7)=464,881 ; \mathrm{p}<0,001)$. Yani, dergilerin sahip oldukları etki puanlarında yayımlandıkları ülkelerin etkisi görülmektedir. Bu istatistikler etki puanı dikkate alınarak yapılan UBYT teşvik sınıflamasında üst sınıflarda yalnızca belirli ülke gruplarına ait dergilerin kaçınılmaz olarak yer alacağını kanıtlayan bir sonuç olarak yorumlanabilir. Bu durumun dikkate alınarak planlama yapılması önemlidir. 


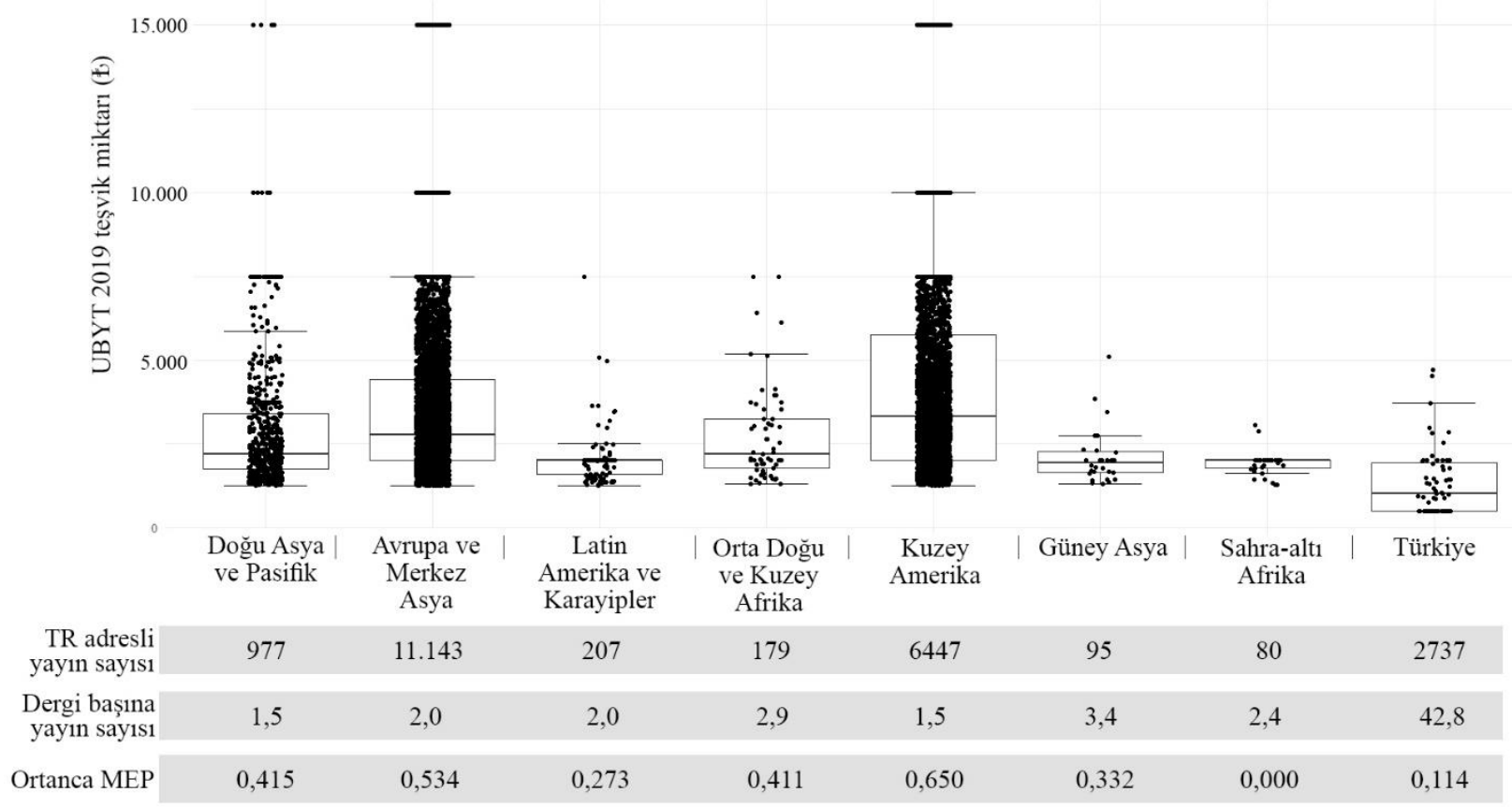

Şekil 7. Teşvik miktarlarının ülke gruplarına dağılımını gösterir kutu grafik

\section{Sonuç ve Öneriler}

UBYT kapsamında desteklenen dergilere daha yakından bakmayı hedefleyen bu çalışmada TÜBITTAK tarafından teşvik verilen dergiler disiplinlerine, puanlarına, teşvik gruplarına ve yayımlandıkları ülkelere göre değerlendirilmiştir. Buna göre Türkiye adresli en çok yayın yapılan, yani programdan en çok yararlanması beklenen grup en düşük değer atfedilen dergilerde yayımlanan makale ve derlemelerdir. 2018 ve 2019 yllarında farklı hesaplama yöntemleri kullanılmış olmasına rağmen Türkiye adresli yayınların çoğu her iki yılda da en alt düzeyde sinıflanan dergilerde yer bulmuştur.

Çalışmanın bulguları 2017 yılında Yaşar Tonta tarafından yapılan çalışmada önerilen değişikliklerin bir kısmının TÜBİTAK ULAKBİM tarafından uygulamaya geçirildiğini göstermesi açısından önemlidir. Ancak, hesaplama yönteminin neredeyse bütünüyle değiştirilmiş olması 2018 yılında üst düzey atfedilen dergilerin bir yıl gibi kısa bir sürede daha az değerli görülmesine, değeri düşük addedilen dergilerin ise aynı sürede çok daha önemli yere gelmesine sebep olmuştur. Bu noktada dergilerin sıralamadaki yerlerinin bu denli değişken oluşu yazarlar ve karar vericiler için kafa karıştırıcı olabilir. Bu sebeple bu gibi önemli değişiklikler yapıldığında ilgililerinin bilgilendirilmesi ve dergi sıralamalarının neye dayanarak yapıldığı ile bu sıralamaların olası sınırlılıklarının ilgililerine aktarılması büyük önem taşımaktadır. Öte yandan mikro ödemeler ile ilgili sorunun da halen devam ettiğini söylemek mümkündür.

Disiplin bazlı analizlere bakıldığında ise bazı alanların teşvik sisteminde yeteri kadar desteklenmediği ortaya çımıştır. Özellikle tüm teşvik ve yükselme programlarında yeri bir türlü belirlenemeyen sanat ve insan bilimlerinin tamamının UBYT'de en düşük teşvik grubunda değerlendirilmesi bu alana yönelik bakış açılarını göstermesi açısından da önemlidir. Literatürde 
sanat ve insan bilimlerinin bilinen hiçbir alana benzemediği pek çok kez dile getirilmiştir (ör. "DORA", 2019; Taşkın ve Doğan, 2019). Avrupa'da sanat ve insan bilimlerine özel araştırma değerlendirme sistemleri geliştirilmesi için 36 ülkenin katılımı ile bir Ufuk 2020 projesi tamamlanmıştır ("ENRESSH", 2019). Buna rağmen bu alanı diğerlerinden ayrı değerlendirmek için gerekli çalışmaların ülkemizde henüz yapılmadığı görülmektedir. UBYT sisteminde disiplin bazlı farklılıklar yalnızca sanat ve insan bilimleri için geçerli değildir. Mühendislik, sosyal bilimler, tarım ve veterinerlik gibi alanlara ait dergiler üst düzey addedilen dergiler arasında yeteri kadar temsil edilememektedir. Elbette bunun temel sebebi bu alanlarda yayımlanan dergilerin makale etki puanlarıdır ancak bu çalışmadan çıkan önemli sonuçlardan biri her bir disiplinin birbirinden dinamikleri olduğu ve her birinin birbirinden ayrı değerlendirilmesi gerektiğinin verilerle ortaya koyulmuş olmasıdır.

Araştırma bulgularına göre MEP değeri yüksek olduğu için yüksek kaliteli olarak etiketlenen dergilerin neredeyse tamamı Kuzey Amerika ve Avrupa dergilerdir. Gelişmekte olan ülkelerin dergileri çoğunlukla son sınıfta yer almaktadır. Ayrıca UBYT kapsamında desteklenen Türkiye adresli tüm dergiler en düşük teşvik grubunda yer almaktadır. Bu durumda mevcut teşvik sisteminin yalnızca bibliyometrik göstergelere (MEP veya etki faktörü) odaklanıyor oluşu sadece belirli bölgelerde yayımlanan dergilerin en kaliteli olarak kabul edilmesine yol açmaktadır. $\mathrm{Bu}$ noktada önemli olan bir diğer konu bu sonuçların farklı bir gözle yorumlanması gerekliliğidir. Bir makalenin herhangi bir dergide yayımlanmasını etkileyen çok fazla unsur bulunmaktadır. Bunlardan bazıları dergilerin makale kabul/ret oranları, popülerliği veya tercih edilirliği, çalışma alanlarının yerel/bölgesel ya da uluslararası olması, büyük araştırma gruplarına ait yayınların kabulünün daha kolay olması veya büyük üniversitelerce yapılan yayınların daha kolay kabul almasıdır. Öte yandan çalışma kapsamında elde edilen en önemli bulgulardan biri makale etki puanı ile ülke grubu arasındaki ilişkidir. Bunun anlamı makale etki puanının bölgelere göre değişiklik göstermesidir. Bilimde belirli seviyelere gelmiş ülkelere ait dergilerin etki puanları yüksek olduğundan UBYT gibi dergi sinıflamalarında her zaman en üst sirada yer alacakları açıktır. Bu açıdan bakıldığında hem disiplin hem de ülke bazlı avantaj/dezavantajlar değerlendirildiğinde üst grupta yer alan dergilerde yalnızca küçük bir azınlığın yayın yapabileceği açıktır. Tüm bu sebeplerle teşvik veya yükselmeler için hazırlanacak dergi listelerinin farklı açılardan ele alınması ve değerlendirilmesi büyük önem taşımaktadır.

UBYT 2019 listesinde yer alan dergilerin \%40'ından fazlasında Türkiye adresli yayın yapılmamıştır. $\mathrm{Bu}$ durumda ilgili listede Türkiye adresli akademisyenlerin çalışma alanına girmeyen pek çok derginin yer bulduğunu söylemek mümkündür. UBYT programının temel amacı elbette araştırmacılar için bir dergi listesi sunmak değildir ve dayandığı temel veri kaynağı JCR olduğu için herhangi bir filtreleme gerçekleştirilmeksizin geniş çaplı bir liste sunulmaktadır. Ancak Avrupa'daki bazı ülkelerde gerçekleştirildiği gibi dergi listelerinin yalnızca dergi temelli ölçevler dikkate alınarak değil, uzman kurullarca gözden geçirilmesi ile bu listelerin daha işlevsel hale getirilmesi mümkün olabilir. Bu sayede yayını için dergi seçiminde zorlanan genç araştırmacılar için bir dergi tavsiye listesi de sunulmuş olacaktır. Gelecek çalışmalarda UBYT 
listesinin genç araştırmacılarca dergi tavsiye listesi olarak kullanılıp kullanılmadığı araştırılırsa bu yönde bir eğilim saptandı̆̆ takdirde listelerin daha işlevsel olması sağlanabilir.

Son olarak akademisyenlerin kabul edilen en temel iki görevi eğitim ve araştırmadır. Akademisyenler kendi alanlarında bilimsel gelişime katkı sağlayabilmek için araştırma yapar ve bulgularını yayınları aracılığı ile paylaşırlar. Çalışmanın başındaki elektriğin icadı örneğinde olduğu gibi her bir araştırma bir sonraki için basamak oluşturur ve bilimi güçlendirir. Ancak üretilenlerin içeriğine bakılmaksızın yalnızca ülke sıralamasını yükseltmek amacı ile parasal teşvikler verilmesi bilimsel araştırmanın doğasına zarar verebilir. Bu sebeple araştırma çıktılarını iyileştirme veya yaygınlaştırmaya yönelik politikalar belirlenirken tamamen bibliyometrik göstergelere dayanan sistemlerin aksayan yönleri değerlendirilerek yalnızca nitelikli araştırmaların desteklenebileceği bir yapının inşasına çalışılmalıdır.

\section{Teşekkür}

$\mathrm{Bu}$ çalışma sekiz Avrupa ülkesi ile Çin'in akademik yükselme, teşvik ve performans değerlendirme sistemlerinin dergilere bakış açılarının karşılaştırıldığı uluslararası/çok uluslu bir araştırmanın ön bulgularını içermektedir. Çalışmanın veri toplama aşamasında veri yapılarını tanımlayan ve araştırma çerçevesini çizen Emanuel Kulczycki ve Ying Huang'a teşekkür ederim.

Yazarın 1 Kasım 2019-31 Ekim 2021 tarihleri arasında gerçekleştirdiği bilimsel araştırmalar Polonya Ulusal Ajansı (NAWA Poland) tarafindan ULAM Programı çerçevesinde fonlanmaktadır (PPN/ULM/2019/1/00062). 


\section{Kaynakça}

Adler, R., Ewing, J. ve Taylor, P. (2009). Citation statistics: A report from the International Mathematical Union (IMU) in cooperation with the International Council of Industrial and Applied Mathematics (ICIAM) and the Institute of Mathematical Statistics (IMS). Statistical Science, 24(1), 1-14. Erişim adresi:

https://www.jstor.org/stable/pdf/20697661.pdf?refreqid=excelsior\%3A30d5020632d945746ecb6c1 ad0bea17c

Akademik Teşvik Ödeneği Yönetmeliğinde Değişiklik Yapılmasına Dair Yönetmelik. (2020, 16 Ocak). Resmi Gazete (Sayı: 31011). Erişim adresi: https://www.resmigazete.gov.tr/eskiler/2020/01/20200117-9.pdf

Al, U. (2010). Atıf dizinlerinde yayın yapılması nereye kadar desteklenecek? Cumhuriyet Bilim ve Teknoloji, 23(1191), 14-15. Erişim adresi: http://yunus.hacettepe.edu.tr/ umutal/publications/CBT.pdf

Article Influence Score. (t.y.). Erişim adresi: http://help.incites.clarivate.com/incitesLiveJCR/glossaryAZgroup/g4/7790-TRS.html

Chodos, A. (2006). March 20, 1800: Volta describes the electric battery. APS News, 15, 3. Erişim adresi: https://www.aps.org/publications/apsnews/200603/history.cfm

Clarivate Analytics. (2012). OECD category to Web of Science category mapping 2012. Erişim adresi: http://help.prod-incites.com/inCites2Live/5305-

TRS/version/default/part/AttachmentData/data/OECD\%20Category\%20Mapping.xlsx

Clarivate. (2018, 7 Şubat). Back to the future: Institute for Scientific Information re-established within Clarivate Analytics. Erişim adresi: https://clarivate.com/news/back-future-institute-scientificinformation-re-established-within-clarivate-analytics/

DORA. (2019). Araştırma değerlendirmesi üzerine San Francisco Deklarasyonu. Erişim adresi: https://sfdora.org/wp-content/uploads/2019/01/DORA_Turkish.pdf

ENRESSH. (2019). About. Erişim adresi: https://enressh.eu/about/

Faraday, M. (1832). V. Experimental researches in electricity. Philosophical Transactions of Royal Society of London. doi: 10.1098/rstl.1832.0006

Franklin, B. (1752). XCV. A letter of Benjamin Franklin, Efq; to Mr. Peter Collinson, F.R.S. concerning an electrical kite. Erişim adresi: https://royalsocietypublishing.org/doi/pdf/10.1098/rstl.1751.0096

Good, B., Vermeulen, N., Tiefenthaler, B. ve Arnold, E. (2015). Counting quality? The Czech performance-based research funding system. Research Evaluation, 24(2), 91-105. doi: 10.1093/reseval/rvu035

Hacettepe Üniversitesi Güzel Sanatlar Fakültesi Öğretim Üyeliğine Yükseltme ve Atama Kriterleri 2019. (2019). Erişim adresi: https://www.hacettepe.edu.tr/akademik/atama/Kriter2019GSF.pdf

Hacettepe Üniversitesi Ögretim Üyeliğine Yükseltme ve Atanma Kriterleri. (2019). Erişim adresi: http://kriter.hacettepe.edu.tr

Kulczycki, E. (2017). Assessing publications through a bibliometric indicator: The case of comprehensive evaluation of scientific units in Poland. Research Evaluation, 26(1), 41-52. doi: 10.1093/reseval/rvw023

Master Journal List. (2020). Downloads. Erişim adresi: https://mjl.clarivate.com/home 
Taşkın, Z. ve Doğan, G. (2019, 2 Temmuz). Akademik performans ölçümünde sanat ve insan bilimleri. Sarkaç. Erişim adresi: https://sarkac.org/2019/07/akademik-performans-olcumunde-sanat-ve-insanbilimleri/

Tenopir, C. ve King, D.W. (2000). Towards electronic journals: Realities for scientists, librarians and publishers. Erişim adresi: http://www.cogsci.ecs.soton.ac.uk/cgi/psyc/newpsy?11.084

The World Bank. (2019). World Bank country and lending groups. Erişim adresi: https://datahelpdesk.worldbank.org/knowledgebase/articles/906519-world-bank-country-andlending-groups

Tonta, Y. (2017a). TÜBİTAK Türkiye Adresli Uluslararası Bilimsel Yayınları Teşvik (UBYT) programının değerlendirilmesi. Ankara: TÜBİTAK ULAKBİM, 2017.

Tonta, Y. (2017b). Does monetary support increase the number of scientific papers? An interrupted time series analysis. 6th International Conference on Scientometrics \& Informetrics: Conference Proceedings, Wuhan University, Wuhan, China, 16-20 Ekim 2017 içinde (s. 1228-1239). Erişim adresi: http://yunus.hacettepe.edu.tr/ tonta/yayinlar/tonta-ISSI2017-paper.pdf

Tonta, Y. ve Akbulut, M. (2019). Does monetary support increase citation impact of scholarly papers?. arXiv:1909.10068. Erişim adresi: http://yunus.hacettepe.edu.tr/ tonta/Yayinlar/tonta_akbulutarxiv.pdf

TÜBİTAK Türkiye Adresli Uluslararası Bilimsel Yayınları Teşvik(UBYT) Programı Uygulama Usul ve Esaslart. (2013). Erişim adresi:

https://www.tubitak.gov.tr/sites/default/files/esaslar_v_2_vers.1.pdf

TÜBİTAK Türkiye Adresli Uluslararası Bilimsel Yayınları Teşvik(UBYT) Programı Uygulama Usul ve Esaslart. (2017). Erişim adresi: https://cabim.ulakbim.gov.tr/wpcontent/uploads/sites/4/2019/01/UBYT_Esaslar\%c4\%b1_2016-2017_v2.pdf

TÜBİTAK Türkiye Adresli Uluslararası Bilimsel Yayınları Teşvik (UBYT) Programı Uygulama Usul ve Esasları. (2018). Erişim adresi: https://cabim.ulakbim.gov.tr/wpcontent/uploads/sites/4/2019/05/2019_UBYT_Uygulama_Usul_ve_Esaslar\%c4\%b1.pdf

UBYT Hakkinda. (2020). Erişim adresi: https://cabim.ulakbim.gov.tr/ubyt/ubyt-hakkinda/

UBYT S.S.S. (2020). Erişim adresi: https://cabim.ulakbim.gov.tr/ubyt/ubyt-s-s-s/

ÜAK. (2019). Tablo 11 - Sosyal, beşeri ve idari bilimler temel alanı. Erişim adresi: http://www.uak.gov.tr/temelalan/TA_Tablo11_2019E_250919.pdf

Vanclay, J. K. (2012). Impact factor: Outdated artefact or stepping-stone to journal certification. Scientometrics, 92, 211-238. doi: 10.1007/s11192-011-0561-0

Yaltırak, C. (2014, 21 Mart). TÜBİTAK yayın teşvik sistemini değiştirmeli! Cumhuriyet Bilim ve Teknoloji, 18. Erişim adresi:

https://www.researchgate.net/profile/Cenk_Yaltirak/publication/261061799_Tubitak_yayin_tesvik _sistemini_degistirmeli/links/02e7e533197561e007000000.pdf

Yuret, T. (2016). Interfield equality: Journals versus researchers. Journal of Informetrics, 10(4), 11961206. doi: 0.1016/j.joi.2016.09.004

Yuret, T. (2017). Do researchers pay attention to publication subsidies? Journal of Informetrics, 11(2), 423-434. doi: 10.1016/j.joi.2017.02.010

Zeigler, D. (2012). Evolution and cumulative nature of science. Evolution: Education and Outreach, 5(4), 585-588. doi: 10.1007/s12052-012-0454-6 


\section{Summary}

Scholarly articles are of great importance in the scholarly communication process as they are the channels in which scientific research is presented. The cumulative nature of science realizes itself through scientific publications. Although scientific journals are intended to be used to enable the development of scientific knowledge by transferring it to the next generations in the past, today, journals play an important role in evaluating research/er performances and incentive/tenure decisions. Nowadays, when journals are of great importance in research evaluation processes, various classifications for journals are made by policymakers and managers based on bibliometric indicators or panel decisions, and researchers are directed to journals considered to be "highquality journals".

In Turkey, tenures and incentives are often given by considering the bibliometric data provided by Web of Science and Journal Citation Reports. One of the most important journal lists is published by TÜBİTAK Incentive Program for International Scientific Publications (UBYT). The main objective of the program is to increase the number of high-quality publications authored by Turkey addressed scholars and to increase the visibility of the publications. The journals are grouped into four basic levels in UBYT program, and the authors are awarded by the program in terms of the levels of the journals ( $500 £-15.000 €)$.

The main data source of the program is the Journal Citation Reports database. Journal ranks are determined according to article influence scores (AIS). Journal impact factor quartiles are used for journals which are indexed in SCI or SSCI and do not have article influence score. Since the A\&HCI database is not included in Journal Citation Reports, all journals in A\&HCI are supported by the program $(2000 €)$. Every year, TUBİTAK ULAKBIM updates the journal list by considering new edition of Journal Citation Reports. Until 2019, the journal lists were determined by using different formulas developed by TÜBİTAK ULAKBIM, however, major changes are made in the calculation method for the 2019 journal list.

The main aim of this study is to carry out discipline-based and country-based analysis by examining the journal list of UBYT program in detail. The main research questions are the following:

- What are the remarkable changes in the UBYT program, which had significant changes in its calculation method in 2019? What are the similarities and differences of the 2018 and 2019 lists?

- Does the article influence score, which is used to determine the incentive amounts, differ according to scientific disciplines in which the journals are published?

- Is there a significant relationship between the incentive classes and disciplines in which the journals are published? Are all disciplines adequately represented in incentive groups?

- Is there a meaningful relationship between the country of origins of journals and incentive classes? What is the place of Turkish journals in the incentive system? In which countries' journals do the Turkey-addressed scholars prefer to publish their papers?

To answer the research questions, 2018 and 2019 journal lists are used. Since the journal list of 2018 based on journal scores from 0 to 100 and the journal list of 2019 is divided by four main categories from A to D, the 2018 journal list is divided into 4 main incentive groups to ensure 
comparability. The details about incentive classifications used in the scope of this study is shown in Table 1.

Table 4

Classifications for 2018 and 2019 Journal Lists

\begin{tabular}{lrrrr}
\hline & & & Amount of incentives & Incentive criteria \\
\hline Incentive group & 2018 & 2019 & 2018 (journal score) & 2019 (AIS) \\
\hline Group D & $7500 €$ & $15,000 €$ & 100 & $3.0+$ \\
Group C & $7499 €-5000 €$ & $10,000 €$ & $83.8-99.9$ & $2.0-2.9$ \\
Group B & $4999 €-2500 €$ & $7500 €$ & $60.6-83.7$ & $1.5-1.9$ \\
Group A & $500 €-2499 €$ & $500 €-7499 €$ & $0-60.5$ & $0.1-1.4$ \\
\hline
\end{tabular}

To find articles and reviews published in the journals in the lists, various search queries were conducted by using Web of Science database. Bibliometric data about Turkey-addressed publications for 2018 and 2019 were downloaded from the database. OECD subject classification was used for discipline classification, and the regional classification developed by the World Bank for country groups. Journals that are indexed in more than one subject categories of OECD were marked as multidisciplinary. R Commander and KMggplot2 plugin were used to visualize the data, and StatPlanet was used to create geographical distributions of the journals.

To summarize the findings obtained from the research:

- The most important differences between 2018 and 2019 journal lists are the decrease in the number of supported journals as a result of the change in the calculation method.

- Although more publications have been produced in 2019 compared to 2018, more of the articles in 2018 appear to be in journals supported by the Program.

- The Turkey-addressed articles and reviews are published in $40 \%$ of the journals in the list for both years.

- With the change of the calculation method, significant changes are determined in the positions of the journals in 2018 and 2019 journal lists.

- Not all disciplines are represented equally in the Program's levels. It appears that the most disadvantaged groups are those working in the agriculture and veterinary sciences, as well as arts and humanities. The number of journals in agriculture and veterinary is limited, and the amount of incentives per journal is low compared to other disciplines. Contrary to common knowledge in finding journal alternative and receiving incentives for publications, UBYT system seems to be disadvantageous not just for arts and humanities, but also agriculture $\&$ veterinary and engineering \& technology.

- $98 \%$ of the D group, which includes top-tier journals, consists of journals from North America and Europe \& Central Asia. The situation is almost the same for in the group C. It is possible to say that many country groups are just placed in the last (low-level) incentive group. All Turkey-addressed journals are classified into the low-level journals because of their low article influence scores.

The results of the research provide findings that may help TÜBİTAK ULAKBİM to improve the processes in the existing UBYT system in terms of providing an effective incentive system. In addition, the study shows the problems of radical changes of the journals lists and warns the policymakers about usage of journal-based bibliometric data for research/er evaluations. 
Ek 1. Disiplinlerin makale etki puanına etkisini gösterir Mann Whitney U testi sonuçları

\begin{tabular}{lrrr}
\hline Ülke grupları & $U$ & $Z$ & $p$ \\
\hline Mühendislik ve teknoloji X Doğa bilimleri & 554382,000 & $-6,269$ & 0,000 \\
Mühendislik ve teknoloji X Tıp ve sağlı bilimleri & 614989,500 & $-6,840$ & 0,000 \\
Mühendislik ve teknoloji X Sosyal bilimler & 412183,000 & $-3,594$ & 0,000 \\
Mühendislik ve teknoloji X Sanat ve insan bilimleri & 34959,500 & $-40,337$ & 0,000 \\
Mühendislik ve teknoloji X Tarım ve veterinerlik & 38798,000 & $-4,824$ & 0,000 \\
Mühendislik ve teknoloji X Çok disiplinli dergiler & 574203,000 & $-2,037$ & 0,000 \\
Doğa bilimleri X Tıp ve sağlık bilimleri & 2661597,000 & $-0,289$ & 0,773 \\
Doğa bilimleri X Sosyal bilimler & 1533328,500 & $-3,221$ & 0,001 \\
Doğa bilimleri X Sanat ve insan bilimleri & 96172,000 & $-50,875$ & 0,000 \\
Doğa bilimleri X Tarım ve veterinerlik & 110961,500 & $-8,516$ & 0,000 \\
Doğa bilimleri X Çok disiplinli dergiler & 1926797,500 & $-6,242$ & 0,000 \\
Tıp ve sağlık bilimleri X Sosyal bilimler & 1716151,500 & $-3,624$ & 0,000 \\
Tıp ve sağlık bilimleri X Sanat ve insan bilimleri & 124936,000 & $-51,397$ & 0,000 \\
Tıp ve sağlık bilimleri X Tarım ve veterinerlik & 120069,000 & $-9,072$ & 0,000 \\
Tıp ve sağlık bilimleri X Çok disiplinli dergiler & 2152873,500 & $-6,840$ & 0,000 \\
Sosyal bilimler X Sanat ve insan bilimleri & 111854,500 & $-46,290$ & 0,000 \\
Sosyal bilimler X Tarım ve veterinerlik & 85016,000 & $-6,933$ & 0,000 \\
Sosyal bilimler X Çok disiplinli dergiler & 1422020,500 & $-2,449$ & 0,014 \\
Sanat ve insan bilimleri X Tarım ve veterinerlik & 11723,500 & $-30,503$ & 0,000 \\
Sanat ve insan bilimleri X Çok disiplinli dergiler & 194249,500 & $-47,060$ & 0,000 \\
Tarım ve veterinerlik X Çok disiplinli dergiler & 119060,000 & $-6,211$ & 0,000 \\
\hline
\end{tabular}

